\title{
1 A new method for scale-up of solvent-based post-combustion carbon capture 2 process with packed columns
}

3 Otitoju Olajide, Eni Oko, Meihong Wang*

${ }^{*}$ Corresponding author: E-mail address: Meihong.wang@sheffield.ac.uk, Tel: +44(0)114 - 2227-160

\section{Abstract}

Solvent-based post-combustion carbon capture (PCC) with packed column is the most commercially ready $\mathrm{CO}_{2}$ capture technology. To study commercial-scale PCC processes, validated pilot scale models are often scaled up to commercial-scale using the generalized pressure drop correlation (GPDC) chart which requires assuming the column pressure drop. The GPDC method may lead to either over-estimation or under-estimation of the column diameter. In this paper, a new method for estimating the packed column diameter without assuming the pressure drop has been proposed and used for model scale-up. The method was validated by scaling between two existing pilot plant sizes. The $\mathrm{CO}_{2}$ capture process was simulated in Aspen Plus ${ }^{\circledR}$ and validated at pilot scale. The validated model was scaled up to commercial $\mathrm{CO}_{2}$ capture plant capable of serving a $250 \mathrm{MW}_{\mathrm{e}}$ combined cycle gas turbine power plant using the new method proposed in this study. The results obtained from the scaleup study were compared to those obtained when the GPDC method was used to design the same commercial $\mathrm{CO}_{2}$ capture plant. The results showed that the GPDC method overestimated the absorber and stripper diameter by $1.6 \%$ and $8.5 \%$ respectively. Process simulation results for the commercial-scale plant showed about $2.12 \%$ and $5.63 \%$ lower solvent flow rate and reboiler duty with the proposed method. Therefore, the capital and operating costs for the process using the newly proposed scale-up method could be lower based on our estimates of the column dimensions, solvent flow rate and specific reboiler duty.

Keywords: post-combustion $\mathrm{CO}_{2}$ capture, chemical absorption, process modelling and simulation, model validation, scale-up, combined cycle gas turbine power plant

\section{Highlights}

- Generalized pressure drop correlation (GPDC) commonly used for scale-up in carbon capture.

- New method to estimate packed column diameter proposed. 
$43 \quad F_{\mathrm{p}} \quad$ packing factor $\left(\mathrm{m}^{-1}\right)$

$44 \quad$ gas mass flow rate $(\mathrm{kg} / \mathrm{s})$

$45 G_{i} \quad$ gas molar flow rate per cross-sectional area $\left(\mathrm{kmol} / \mathrm{m}^{2} \mathrm{~s}\right)$

$46 \quad H_{\mathrm{OG}}$ height of the transfer unit (m)

$47 \quad K_{\mathrm{G}} \quad$ overall gas-phase mass transfer coefficient $\left(\mathrm{kmol} / \mathrm{m}^{3} \mathrm{~s}\right.$ bar)

$48 \quad k_{\mathrm{j}}^{\mathrm{o}} \quad$ pre-exponential factor $\left(\mathrm{m}^{3} / \mathrm{kmol} . \mathrm{s}\right)$

$49 \quad L \quad$ solvent mass flow rate $(\mathrm{kg} / \mathrm{s})$

$50 \quad M_{M E A}$ molar mass of MEA $(\mathrm{kg} / \mathrm{kmol})$

$51 n$ Temperature factor

$52 \quad N_{\text {OG }}$ overall number of the transfer unit

$53 \quad P \quad$ pressure (bar)

$54 \Delta P_{\mathrm{fl}} \quad$ flooding pressure drop (in. $\left.\mathrm{H}_{2} \mathrm{O} / \mathrm{ft}\right)$

$55 \quad R \quad$ ideal gas constant $(\mathrm{J} / \mathrm{K} \mathrm{mol})$

$56 R_{j} \quad$ Reaction rate for reaction $j,\left(\mathrm{~m}^{3} / \mathrm{kmol} . \mathrm{s}\right)$

$57 \quad T \quad$ Temperature $(\mathrm{K})$

$58 V_{G, f l} \quad$ flooding velocity $(\mathrm{m} / \mathrm{s})$

$59 V_{\mathrm{G}} \quad$ superficial gas velocity $(\mathrm{m} / \mathrm{s})$

$60 y \quad$ mole fraction of $\mathrm{CO}_{2}$ in the gas phase at any point in the column

$61 y_{\mathrm{CO}_{2, \text { in }}}$ mole fraction of $\mathrm{CO}_{2}$ in the inlet gas 
$62 y_{\mathrm{CO}_{2, \text { out }}}$ mole fraction of $\mathrm{CO}_{2}$ in the outlet gas

$63 y^{*} \quad$ gas-phase mole fraction of $\mathrm{CO}_{2}$ in equilibrium with $\mathrm{CO}_{2}$ concentration in the liquid

$64 z \quad$ number of equivalents/moles of amine (1 for MEA)

$65 \mathrm{Z}_{\mathrm{T}} \quad$ packing height (m)

66

$67 \quad$ Greek letters

$68 \alpha_{\text {Lean }}$ lean loading ( $\mathrm{mol} \mathrm{CO}_{2} / \mathrm{mol} \mathrm{MEA)}$

$69 \alpha_{\text {Rich }}$ rich loading (mol $\left.\mathrm{CO}_{2} / \mathrm{mol} \mathrm{MEA}\right)$

$70 \Delta \alpha \quad$ absorption capacity ( $\left.\mathrm{mol} \mathrm{CO}_{2} / \mathrm{mol} \mathrm{MEA}\right)^{\circ}$

$71 \quad \alpha_{\mathrm{ij}} \quad$ specie $i$ reaction order in reaction $j$

$72 \quad \rho_{\mathrm{G}} \quad$ gas density $\left(\mathrm{kg} / \mathrm{m}^{3}\right)$

$73 \rho_{\mathrm{L}} \quad$ liquid density $\left(\mathrm{kg} / \mathrm{m}^{3}\right)$

$74 \quad \varepsilon \quad$ porosity

$75 \quad v \quad$ kinematic viscosity (cst)

$76 \varphi_{\mathrm{CO}_{2}}$ percentage of $\mathrm{CO}_{2}$ captured

$77 \omega_{M E A}$ MEA concentration (wt $\left.\%\right)$

79 Abbreviations

80 CCGT Combined Cycle Gas Turbine

81 GPDC Generalized pressure drop correlation

82 HETP Height Equivalent to the Theoretical Plate

83 PCC Post-Combustion Carbon Capture

84 PRE Percentage relative error

85 SRP Separation Research Programme

87 1. Introduction

\subsection{Background}

89 There is an increasing concern about global warming effect arising from the emission of 90 greenhouse gases (GHGs). Anthropogenic $\mathrm{CO}_{2}$ emissions from different sources constitute 91 about $80 \%$ of the total GHG emissions (Sreedhar et al., 2017), and $\mathrm{CO}_{2}$ emissions from fossil 
fuel-fired power plants are responsible for approximately about $25 \%$ of the total GHG (Soltani et al., 2017; EPA, 2017).This indicates that efforts at reducing GHG emissions must be targeted at cutting down $\mathrm{CO}_{2}$ emissions from these facilities. One way to achieve this is through the deployment of cost-effective $\mathrm{CO}_{2}$ capture technologies in fossil fuel-fired power plants.

There are three technological options for $\mathrm{CO}_{2}$ capture: pre-combustion, oxy-fuel combustion and post-combustion. Among these capture technologies, post-combustion $\mathrm{CO}_{2}$ capture through chemical absorption with amines is the most mature technology to be used to cut down $\mathrm{CO}_{2}$ emissions from power plants (Wang et al., 2011). In addition to this, the technology is considered the best option for retrofit as its implementation in an existing power plant requires very little modifications (Rezazadeh et al., 2017). Despite these advantages, the commercial implementation of the solvent-based PCC process is faced with a number of challenges such as high capital cost and high energy consumption.

\subsection{Previous studies}

Process modelling and simulation is critical to the design and operation of the PCC plant, and several studies with focus on model development for the plant have been carried out (Awoyomi et al., 2019; Bui et al., 2018; Enaasen et al., 2015; Garcia et al., 2017; Khan et al., 2011; Lawal et al., 2009; Soltani et al., 2017; Zhang et al., 2009). Earlier studies focussed on model development for the standalone absorber (Khan et al., 2011; Kvamsdal et al., 2009; Lawal et al., 2009; Zhang et al., 2009) and the standalone stripper (Greer et al., 2010; Ziaii et al., 2009). This was followed by model development for the whole solvent-based PCC plant (Gaspar and Cormos, 2012; Harun et al., 2012; Lawal et al., 2010; Warudkar et al., 2013; Zhang and Chen, 2013). The reliability of the models' predictions was validated using published experimental data collected from various pilot plants around the world. Experimental data to which model predictions are commonly compared in the literature are the $\mathrm{CO}_{2}$ capture level (Errico et al., 2016; Harun et al., 2012; Lawal et al., 2009; Razi et al., 2013; Zhang et al., 2009), rich solvent $\mathrm{CO}_{2}$ loading (Enaasen Flø et al., 2015; Khan et al., 2011; Luo and Wang, 2017), temperature profile (Bui et al., 2014; Canepa et al., 2013; Garcia et al., 2017; Khan et al., 2011; Lawal et al., 2009; Razi et al., 2013), $\mathrm{CO}_{2}$ concentration profiles (Khan et al., 2011; Luo and Wang, 2017; Razi et al., 2013), desorbed $\mathrm{CO}_{2}$ (Garcia et al., 2017) and specific heat duty (Agbonghae et al., 2014; Luo and Wang, 2017).

Zhang et al. (2009) validated the rate-based absorber model developed in Aspen Plus ${ }^{\circledR}$ with a pilot plant data by the Separations Research Programmes (SRP) at the University of Texas. 
The model was validated against the following parameters: $\mathrm{CO}_{2}$ capture level, $\mathrm{CO}_{2}$ loadings, and temperature profiles. The model predictions showed excellent agreement with the pilot plant data for each of the parameters. Khan et al. (2011) validated their rate-based model with the pilot and industrial-scale experimental data collected from the studies of Pintola et al. (1993), Tontiwachwuthikul et al. (1992) and Aroonwilas et al. (2001). The model predictions matched experimental measurements for the liquid phase MEA and gas-phase $\mathrm{CO}_{2}$ concentrations and the liquid phase temperature profiles.

In order to design and study the possible requirements of a commercial-scale MEA-based $\mathrm{CO}_{2}$ capture process, the validated pilot-scale models are often scaled to commercial scale. Several researchers (Agbonghae et al., 2014; Awoyomi et al., 2019; Biliyok and Yeung, 2013; Canepa et al., 2013; Dutta et al., 2017; Lawal et al., 2012; Nittaya et al., 2014) have performed model scale-up of the process from pilot scale to commercial scale. Lawal et al. (2012) designed a commercial $\mathrm{CO}_{2}$ capture plant that is capable of capturing $90 \%$ of $\mathrm{CO}_{2}$ from the flue gas stream of a $500 \mathrm{MW}_{\mathrm{e}}$ subcritical coal-fired power plant by scaling-up the validated $\mathrm{CO}_{2}$ capture pilot plant model developed in gPROMS. Using the generalized pressure drop correlation chart (GPDC), they developed a capture plant with two absorbers each of diameter $9 \mathrm{~m}$ and height $27 \mathrm{~m}$ and a stripper having the same diameter as the absorber. Similarly, Nittaya et al. (2014) scaled up the $\mathrm{CO}_{2}$ capture pilot plant model developed in gPROMS to a commercial $\mathrm{CO}_{2}$ capture plant capable of capturing $87 \%$ of $\mathrm{CO}_{2}$ from the flue gas of a $700 \mathrm{MW}_{\mathrm{e}}$ supercritical coal-fired power plant. Their scale-up resulted in a commercial $\mathrm{CO}_{2}$ capture plant with three absorbers, each with a diameter of $11.8 \mathrm{~m}$ and height of $34 \mathrm{~m}$ and two strippers each having a diameter of $10.4 \mathrm{~m}$ and height of $16 \mathrm{~m}$. Agbonghae et al. (2014) scaled up a validated $\mathrm{CO}_{2}$ capture pilot plant model developed in Aspen Plus ${ }^{\circledR}$ to a commercial $\mathrm{CO}_{2}$ capture plant capable of capturing $90 \%$ of $\mathrm{CO}_{2}$ from the flue gas of a $400 \mathrm{MW}_{\mathrm{e}}$ CCGT power plant. They came up with a $\mathrm{CO}_{2}$ capture plant with two absorbers, each with a diameter of $11.93 \mathrm{~m}$ and height of $19.06 \mathrm{~m}$ and a stripper with a diameter of $6.76 \mathrm{~m}$ and height of $28.15 \mathrm{~m}$. In all the studies above, the commercial-scale designs of the absorber and the stripper are based on the GDPC methodwhich involves assuming the column pressure drop. This study is focussed on developing an alternative method to estimate the diameter of the packed column for solvent-based PCC process using an empirical correlation that estimates the flooding gas velocity. This allows the diameter of the packed column to be calculated without assuming the pressure drop.

\subsection{Aims and novelty of this study}


Model scale-up from pilot scale to commercial scale for the solvent-based PCC will not only help in providing insights into plant operations but also foresee any commercial-scale development and operational bottlenecks. For the solvent-based PCC process, the packed bed absorber and the stripper are the two largest components in terms of size (Agbonghae et al., 2014; Lawal et al., 2012) and cost (Abu-Zahra et al., 2007). Their design as reported in the literature is based on chemical engineering principles using the GPDC method. Sinnott (2005) recommended a pressure drop range of 147 to $490 \mathrm{~Pa} / \mathrm{m}$ of packing for packed column design at commercial scale. Within this pressure drop range, experimental data are only available at 206 and $412 \mathrm{~Pa} / \mathrm{m}$ of packing on the GPDC chart thereby limiting the choice of pressure drop that can be assumed within this range. Furthermore, data interpolation for pressure drop are difficult and could lead to inaccurate estimates. In existing studies (Agbonghae et al., 2014; Awoyomi et al., 2019; Canepa et al., 2013; Dutta et al., 2017; Lawal et al., 2012; Luo and Wang, 2017; Nittaya et al., 2014), pressure drop of either 206 or $412 \mathrm{~Pa} / \mathrm{m}$ of packing has been assumed. To address this limitation, this study aims to propose an alternative method to estimate the packed column diameter that does not require assuming the column pressure drop. The method involves an algebraic equation derived for the flooding velocity from flooding point experimental correlations reported in the literature. As far as open literature is concern, this attempt is first of its kind. In addition, this approach has been validated in this study by scaling between two existing pilot plants sizes, a similar demonstration could not be found in literature for reported scale-up studies of the process. The method developed in this study is used to scale up the pilot plant model developed in Aspen Plus ${ }^{\circledR}$ to a commercial $\mathrm{CO}_{2}$ capture plant. And the results compared to scale-up study results obtained with the GPDC method.

\section{Methodology}

\subsection{Model development}

The closed-loop model of the $\mathrm{CO}_{2}$ absorption and stripping process was developed in Aspen Plus ${ }^{\circledR}$ V8.4. The absorber and stripper model were developed using the RadFrac rate-based model The rate-based calculations give more reliable results in comparison to the equilibriumbased model counterpart (Lawal et al., 2009). This is because, in the rate-based model, equilibrium is assumed to be achieved only at the vapour-liquid interface and separation is caused by the mass transfer of component between the contacting phases. On the other hand, the equilibrium-based model assumed that each theoretical stage is made up of a well-mixed vapour and liquid phases in equilibrium with each other. This assumption is an approximation 
because, in real column, the contacting phases are never in equilibrium (Zhang et al., 2009). The dimensions of the RadFrac columns were specified to be the same as those of the pilot plants as shown in Tables 4 and 6.

\subsubsection{Thermodynamic and kinetic models}

The liquid phase of the MEA- $\mathrm{H}_{2} \mathrm{O}-\mathrm{CO}_{2}$ system is an electrolyte solution whose accurate modelling requires the selection of a base method that can account for the electrolytes in Aspen Plus ${ }^{\circledR}$. The Electrolyte Non-Random-Two-Liquid (eNRTL) activity coefficient model (Chen and Evans, 1986) was used to calculate the activity coefficient and the SRK equation of state (Soave, 1972) was used to calculate the fugacity coefficient. Other important thermodynamic properties such as Henry's constant, vapour pressure, the heat of absorption and specific heat capacity are calculated using correlations within the eNRTL thermodynamic method in Aspen properties ${ }^{\circledR}$. The equations describing the equilibrium reactions are defined as follows (Aspen Technology, 2008):

$$
\begin{aligned}
& 2 \mathrm{H}_{2} \mathrm{O} \leftrightarrow \mathrm{H}_{3} \mathrm{O}^{+}+\mathrm{OH}^{-} \\
& \mathrm{CO}_{2}+2 \mathrm{H}_{2} \mathrm{O} \leftrightarrow \mathrm{H}_{3} \mathrm{O}^{+}+\mathrm{HCO}_{3}{ }^{-} \\
& \mathrm{HCO}_{3}{ }^{-}+\mathrm{H}_{2} \mathrm{O} \leftrightarrow \mathrm{H}_{3} \mathrm{O}^{+}+\mathrm{CO}_{3}{ }^{2-} \\
& \mathrm{MEACOO}^{-}+\mathrm{H}_{2} \mathrm{O} \leftrightarrow \mathrm{MEA}+\mathrm{HCO}_{3}{ }^{-} \\
& \mathrm{MEAH}^{+}+\mathrm{H}_{2} \mathrm{O} \leftrightarrow \mathrm{MEA}+\mathrm{H}_{3} \mathrm{O}^{+}
\end{aligned}
$$

The equilibrium constants for reactions R1 to R5 are calculated from the Gibbs free energy change, and the equilibrium reactions are assumed to occur in the liquid film. In the rate-based model, the reactions R6 and R7 representing the forward and backward reactions for the formation of bicarbonate and the reactions R8 and R9 representing the forward and backward reactions for the formation of carbamate are considered as kinetics-controlled reactions ( Zhang and Chen, 2013).

$$
\begin{aligned}
& \mathrm{CO}_{2}+\mathrm{OH}^{-} \rightarrow \mathrm{HCO}_{3}^{-} \\
& \mathrm{HCO}_{3}{ }^{-} \rightarrow \mathrm{CO}_{2}+\mathrm{OH}^{-} \\
& \mathrm{MEA}+\mathrm{CO}_{2}+\mathrm{H}_{2} \mathrm{O} \rightarrow \mathrm{MEACOO}^{-}+\mathrm{H}_{3} \mathrm{O}^{+} \\
& \mathrm{MEACOO}^{-}+\mathrm{H}_{3} \mathrm{O}^{+} \rightarrow \mathrm{CO}_{2}+\mathrm{H}_{2} \mathrm{O}+\mathrm{MEA}
\end{aligned}
$$


The reaction rates for reactions R6 to R9 can be calculated by the power law which is described in Aspen Plus ${ }^{\circledR}$ by the following equation.

$$
R_{j}=k_{j}^{o} T^{n} \exp \left[-\frac{E_{j}}{R}\left(\frac{1}{T}-\frac{1}{298.15}\right)\right] \prod_{i=1}^{N} C_{i}^{\alpha_{i j}}
$$

The values of $k_{j}{ }^{\circ}$ and $E_{j}$ in equation 1 used for reactions R6 to R9 are shown in Table 1.

Table 1

Parameter of the pre-exponential factor and activation energy (Aspen Technology, 2008).

\begin{tabular}{llll}
\hline Reactions & Reaction direction & $k_{j}^{o}\left(\mathrm{kmol} / \mathrm{m}^{3} \mathrm{~s}\right)$ & $E_{j}(\mathrm{~kJ} / \mathrm{mol})$ \\
\hline R6 & Forward & $4.32 \times 10^{13}$ & 55.43 \\
\hline R7 & Reverse & $2.38 \times 10^{17}$ & 123.22 \\
\hline R8 & Forward & $9.77 \times 10^{10}$ & 41.24 \\
\hline R9 & Reverse & $2.18 \times 10^{19}$ & 59.19
\end{tabular}

\subsubsection{Transport property models}

Transport property models, namely density, viscosity, thermal conductivity, surface tension, and diffusivity have been calculated using the correlations summarised in Table 2.

Table 2

Summary of models for calculating transport properties (Aspen Technology, 2001).

\begin{tabular}{|l|l|l|}
\hline Property & Gas-phase & Liquid phase \\
\hline Density & $\begin{array}{l}\text { COSTALD model by Hankinson and } \\
\text { Thomson }\end{array}$ & Clark density model \\
\hline Viscosity & Chapman-Enskog-Brokaw model & Jones-Dole model \\
\hline Thermal conductivity & Wassiljewa-Mason-Sexena model & Riedel model \\
\hline Surface tension & & Onsager-samaras model \\
\hline Diffusivity & Chapman-Enskog-Wilke-Lee model & Wilke-Chang model \\
\hline
\end{tabular}

\subsubsection{Heat and mass transfer calculations}

Heat and mass transfer calculations have been performed using correlations for the mass transfer coefficient, heat transfer coefficient, interfacial area, and the liquid holdup. A summary of the correlations is given in Table 3 . 
Table 3

235 Summary of correlations used for mass and heat transfers

\begin{tabular}{|l|l|l|}
\hline \multirow{2}{*}{ Correlations } & \multicolumn{2}{|c|}{ References } \\
\cline { 2 - 3 } & Absorber & Stripper \\
\hline $\begin{array}{l}\text { Liquid and gas film mass } \\
\text { transfer coefficient }\end{array}$ & Onda et al. (1968) & Bravo et al. (1985) \\
\hline Heat transfer coefficient & Chilton and Colburn (1934) & Chilton and Colburn (1934) \\
\hline Liquid holdup & Stichlmair et al. (1989) & Bravo et al. (1992) \\
\hline Effective Interfacial area & Onda et al. (1968) & Bravo et al. (1985) \\
\hline
\end{tabular}

\section{Model validation}

In this study, pilot plant data from the Separation Research Programme (SRP) at the University of Texas at Austin, USA (Dugas, 2006) and the Brindisi $\mathrm{CO}_{2}$ capture plant located in Brindisi, Italy (Enaasen, 2015) were used to validate the performance of the rate-based model presented in the previous section.

\subsection{Model validation using the SRP pilot plant data}

243 Experimental data collected at the SRP pilot plant which is a multifunctional test facility were used to validate the rate-based model. The SRP pilot plant uses synthetic flue gas produced by mixing air and $\mathrm{CO}_{2}$ gas. The absorber and the stripper both have internal diameter of $0.427 \mathrm{~m}$ and a total height of $11.1 \mathrm{~m}$. The columns are each made up of two $3.05 \mathrm{~m}$ bed of packing with plate collector and liquid redistributor between them. It is capable of handling flue gas flow rate ranging from $330-830 \mathrm{~m}^{3} / \mathrm{h}$ and can capture between 125 and $250 \mathrm{~kg}$ of $\mathrm{CO}_{2} / \mathrm{h}$. The main process conditions, dimensions of the absorbers and the strippers, and the type of packings used in the pilot plant for the three selected cases are summarized in Tables 4 .

Table 4

252

Pilot plant data from the $\mathrm{SRP} \mathrm{CO}_{2}$ capture plant (Dugas, 2006)

\begin{tabular}{|l|c|c|c|}
\hline Cases & 28 & 32 & 47 \\
\hline Flue gas flow rate $\left(\mathrm{m}^{3} / \mathrm{min}\right)$ & 11.00 & 5.48 & 8.22 \\
\hline Flue gas $\mathrm{CO}_{2}$ concentration $(\mathrm{mol} \%)$ & 16.54 & 17.66 & 18.41 \\
\hline Flue gas temperature $\left({ }^{\circ} \mathrm{C}\right)$ & 47.98 & 46.56 & 59.23 \\
\hline Flue gas pressure $(\mathrm{bar})$ & 1.05 & 1.05 & 1.03 \\
\hline Lean solvent flow rate $\left(\mathrm{m}^{3} / \mathrm{min}\right)$ & 0.08 & 0.04 & 0.03 \\
\hline Lean solvent temperature $\left({ }^{\circ} \mathrm{C}\right)$ & 40.00 & 40.56 & 40.07 \\
\hline
\end{tabular}




\begin{tabular}{|l|c|c|c|}
\hline Absorber pressure (bar) & 1.00 & 1.00 & 1.00 \\
\hline Regenerator pressure (bar) & 1.62 & 1.62 & 0.68 \\
\hline & Absorber & \multicolumn{2}{|c|}{ Stripper } \\
\hline Diameter (m) & 0.43 & 0.43 \\
\hline Packing height (m) & 6.10 & 6.10 \\
\hline Packing type & IMTP 40 & Flexipac 1Y \\
\hline
\end{tabular}

253

254

255

256

257

258

259

260

261

262

263

264

265

266

267

268

269

270

The three experimental cases selected for model validation from the 48 experimental runs conducted at the SRP facility have different $\mathrm{CO}_{2}$ concentrations and L/G ratios. Model validation was performed by comparing the model predictions for the $\mathrm{CO}_{2}$ capture level and $\mathrm{CO}_{2}$ loadings against experimental data for different feed conditions. The percentage $\mathrm{CO}_{2}$ capture level and the $\mathrm{CO}_{2}$ loading in the MEA solvent are calculated using Eqs. 2 and 3.

$$
\text { Capture level }(\%)=\left(\frac{y_{\mathrm{CO}_{2, \text { in }}-y_{\mathrm{CO}_{2, \text { out }}}}}{y_{\mathrm{CO}_{2, \text { in }}}}\right) * 100
$$

$$
\text { Loading }=\frac{\left[\mathrm{CO}_{2}\right]+\left[\mathrm{HCO}_{3}^{-}\right]+\left[\mathrm{CO}_{3}^{2-}\right]+\left[\mathrm{MEACOO}^{-}\right]}{[\mathrm{MEA}]+\left[\mathrm{MEA}^{+}\right]+\left[\mathrm{MEACOO}^{-}\right]}
$$

Table 5 shows the model performance results against the experiment. There is a good agreement between the model predictions and the experiment data for all the variables outlined in Table 5. The percentage relative errors (PRE) of the model prediction against the experimental data are calculated as follows:

$$
\text { PRE }=\frac{\left|i_{\text {experiment }}-i_{\text {model }}\right|}{i_{\text {experiment }}} * 100
$$

Fig.1 presents the comparison between the measured and predicted liquid phase temperature profiles along the height of the absorber and the stripper. The model generally gives a good prediction of the temperature profiles in the absorber and the stripper for the three selected cases. Also, the model accurately predicted the location of the temperature bulge (maximum temperature) in the absorber for the three cases as illustrated by curves a, c and e). The location and magnitude of the temperature bulge depend on L/G ratio (Plaza and Rochelle, 2011). Dugas (2006) found that the temperature bulge was located at the top of the absorber with $\mathrm{L} / \mathrm{G}$ 
271 less than $5 \mathrm{~kg} / \mathrm{kg}$ and at the bottom with $\mathrm{L} / \mathrm{G}$ greater than $6 \mathrm{~kg} / \mathrm{kg}$. This explains the location 272 of the temperature bulge close to the bottom of the absorber packing for curves $a$ and $c$ $273(\mathrm{~L} / \mathrm{G}=6.6 \mathrm{~kg} / \mathrm{kg})$ and close to the top of the absorber packing for curve $e(\mathrm{~L} / \mathrm{G}=3.4 \mathrm{~kg} / \mathrm{kg})$.

\section{Table 5}

275 Model performance against experimental data for the $\mathrm{SRP} \mathrm{CO}_{2}$ capture pilot plant

\begin{tabular}{|l|l|l|l|l|l|l|l|l|l|}
\hline Cases & \multicolumn{2}{|l|}{$\begin{array}{l}\text { Lean loading } \\
(\mathrm{mol} \mathrm{CO} / \mathrm{mol} \text { MEA })\end{array}$} & \multicolumn{2}{l|}{$\begin{array}{l}\text { Rich loading } \\
(\mathrm{mol} \mathrm{CO} / \mathrm{mol} \mathrm{MEA})\end{array}$} & \multicolumn{3}{l|}{$\mathrm{CO}_{2}$ capture level (\%) } \\
\hline & Exp. & Model & $\begin{array}{l}\text { PRE } \\
(\%)\end{array}$ & Exp. & Model & $\begin{array}{l}\text { PRE } \\
(\%)\end{array}$ & Exp. & Model & $\begin{array}{l}\text { PRE } \\
(\%)\end{array}$ \\
\hline 28 & 0.28 & 0.28 & 0.00 & 0.41 & 0.41 & 0.00 & 86 & 85 & 1.16 \\
\hline 32 & 0.27 & 0.27 & 0.00 & 0.43 & 0.43 & 0.00 & 95 & 90 & 5.26 \\
\hline 47 & 0.28 & 0.30 & -6.60 & 0.53 & 0.48 & 9.43 & 69 & 69 & 0.00 \\
\hline
\end{tabular}

276

(a)

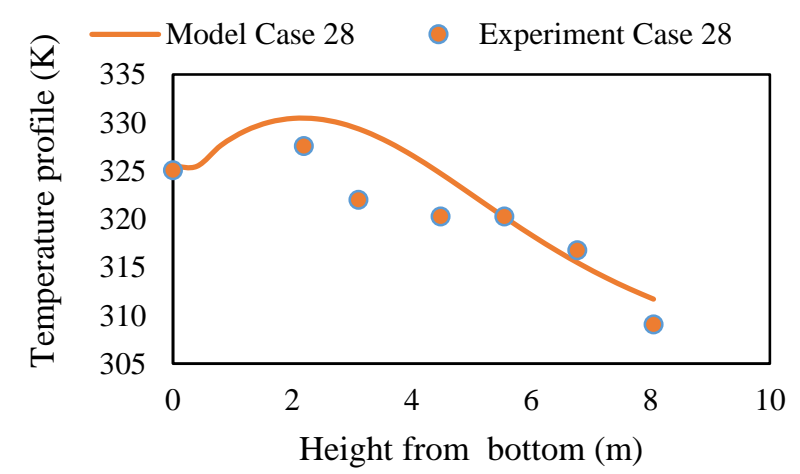

277 (b)

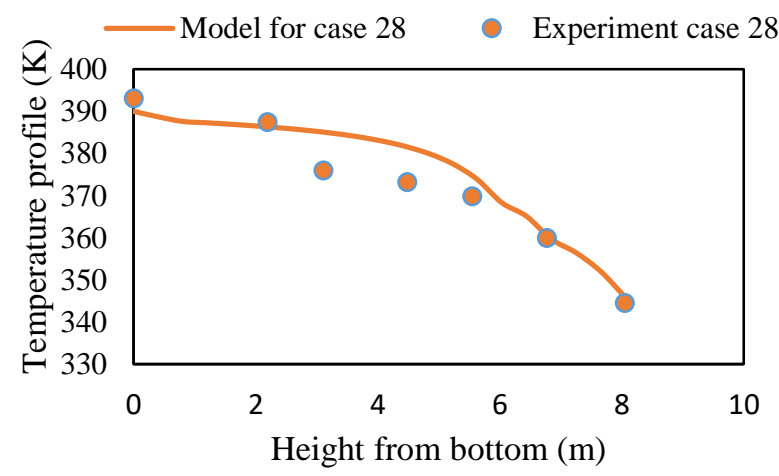

(d)

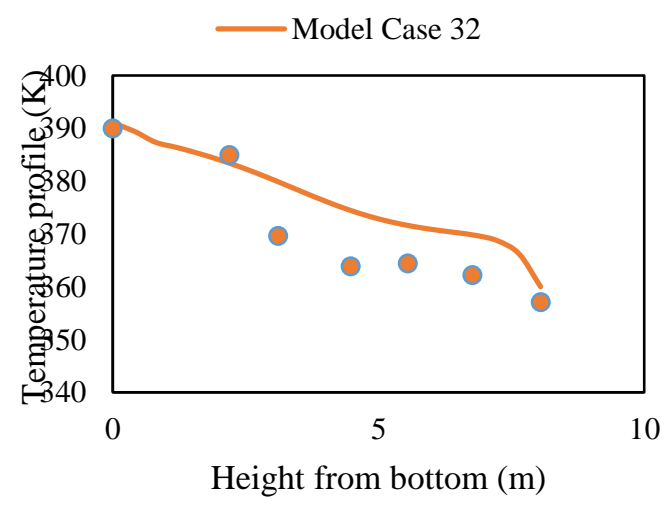

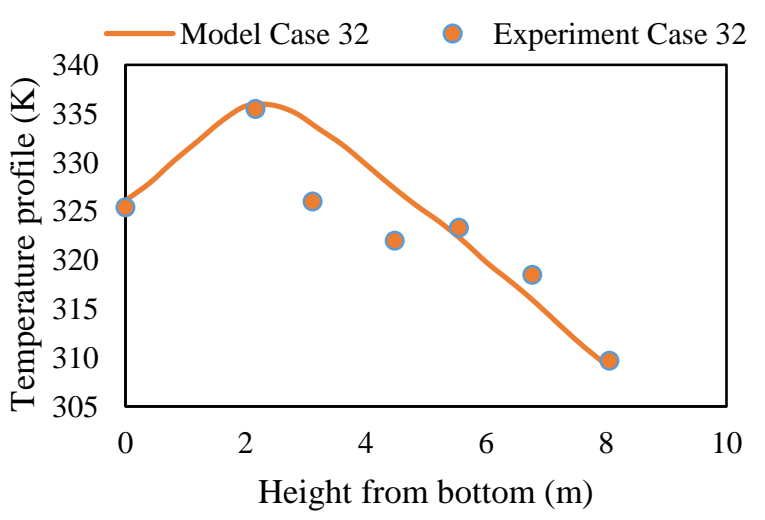


(e)

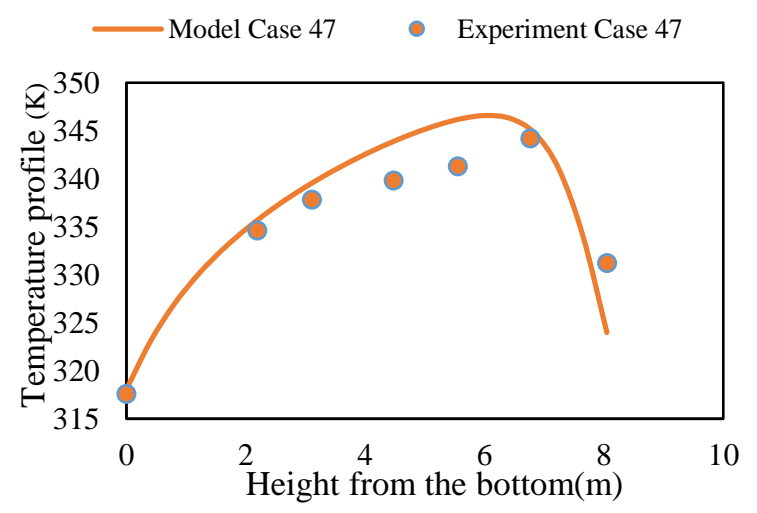

(f)

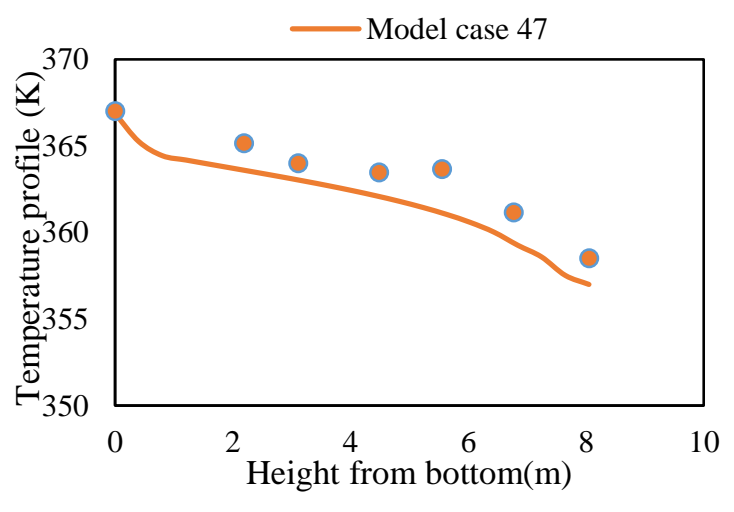

280

Fig. 1. Model predictions against experimental data for temperature profiles in the absorber (a, c, e) and in the stripper (b, d, and f) of the SRP pilot plant for the three cases.

\subsection{Model validation using the Brindisi pilot plant data}

The rate-based capture model was also validated using experimental data collected at the Brindisi pilot plant (Enaasen, 2015). It is a relatively large plant compared to the SRP pilot plant described in section 3.1. The pilot plant uses a flue gas produced from one of the four units (each with capacity of $660 \mathrm{MW}_{\mathrm{e}}$ ) of a coal-fired power plant. The absorber and stripper have diameters of $1.5 \mathrm{~m}$ and $1.3 \mathrm{~m}$, and packing heights of $22 \mathrm{~m}$ and $11 \mathrm{~m}$ respectively. It can capture up to $2500 \mathrm{~kg}$ of $\mathrm{CO}_{2} / \mathrm{h}$ from a flue gas slipstream and has a maximum capacity of 9212 $\mathrm{m}^{3} / \mathrm{h}$ which corresponds to about $0.45 \%$ of the total flue gas produced from the unit four of the power plant (Lemaire et al., 2014). The solvent flow rate can be varied between $20-80 \mathrm{~m}^{3} / \mathrm{h}$. The main process conditions, dimensions of the absorbers and the strippers, and the type of packings used in the pilot plants for the selected cases are summarized in 6 .

\section{Table 6}

Pilot plant data from the Brindisi $\mathrm{CO}_{2}$ capture plant (Enaasen, 2015).

\begin{tabular}{|l|l|l|l|l|l|}
\hline Cases & 2 & 3 & 4 & 5 & 7 \\
\hline Flue gas flow rate $\left(\mathrm{Nm}^{3} / \mathrm{h}\right)$ & 9876 & 9929 & 9893 & 9949 & 9921 \\
\hline Flue gas $\mathrm{CO}_{2}$ concentration $($ dry vol\%) & 11.00 & 12.50 & 12.00 & 10.40 & 11.00 \\
\hline Flue gas temperature $\left({ }^{\circ} \mathrm{C}\right)$ & 46.20 & 44.80 & 45.60 & 44.70 & 46.90 \\
\hline Lean solvent flow rate $\left(\mathrm{m}^{3} / \mathrm{h}\right)$ & 30 & 30 & 30 & 35 & 35 \\
\hline Lean solvent temperature $\left({ }^{\circ} \mathrm{C}\right)$ & 46.90 & 47.00 & 47.00 & 47.00 & 47.10 \\
\hline Lean solvent MEA concentration $(\mathrm{wt} \%)$ & 29.60 & 29.80 & 29.80 & 29.80 & 29.70 \\
\hline & \multicolumn{7}{|c|}{ Absorber } & \multicolumn{5}{|c}{ Stripper } \\
\hline
\end{tabular}




\begin{tabular}{|l|c|c|}
\hline Diameter $(\mathrm{m})$ & 1.50 & 1.30 \\
\hline Packing height $(\mathrm{m})$ & 22 & 11 \\
\hline Pressure (bar) & 1.00 & 1.84 \\
\hline
\end{tabular}

296

297

298

299

300

301

302

303

304

305

306

307

308

309

310

311

312

313

314

Five experimental cases (Table 6) with the least relative deviations in steady-state $\mathrm{CO}_{2}$ mass balance were selected for the model validation among the 12 experimental cases reported. Two sets of packings were used in the absorber and stripper during the model validation. The first set of packing (Mellapak 250X and IMTP 50) is the original packings used in the Brindisi pilot plant during the experiments while the second set of packing (IMTP 40 and Flexipac 1Y) is the packing used in the SRP pilot plant. This was done to:

1. Enable the scale-up from the SRP pilot plant to the Brindisi pilot plant in order to validate the proposed scale-up approach presented later in section 4.

2. Enable the scale-up of the Brindisi pilot plant model (using the second set of packing) to a commercial $\mathrm{CO}_{2}$ capture plant (Section 5.2) using the proposed scale-up method. The results obtained from the scale-up will be compared to those obtained from a commercial $\mathrm{CO}_{2}$ capture plant designed by Canepa et al. (2013) using the same set of packings and the GPDC method.

The parity plot of the rich solvent $\mathrm{CO}_{2}$ loading, desorbed $\mathrm{CO}_{2}$ and specific duty predicted by the model using the two sets of packings against experimental data are shown in Figs. 2-4. The validation results show good agreement between the model predictions and experimental data. The results further demonstrate that the sets of packing used in the columns have identical performance in terms of rich $\mathrm{CO}_{2}$ loading, amount of $\mathrm{CO}_{2}$ desorbed and specific duty.

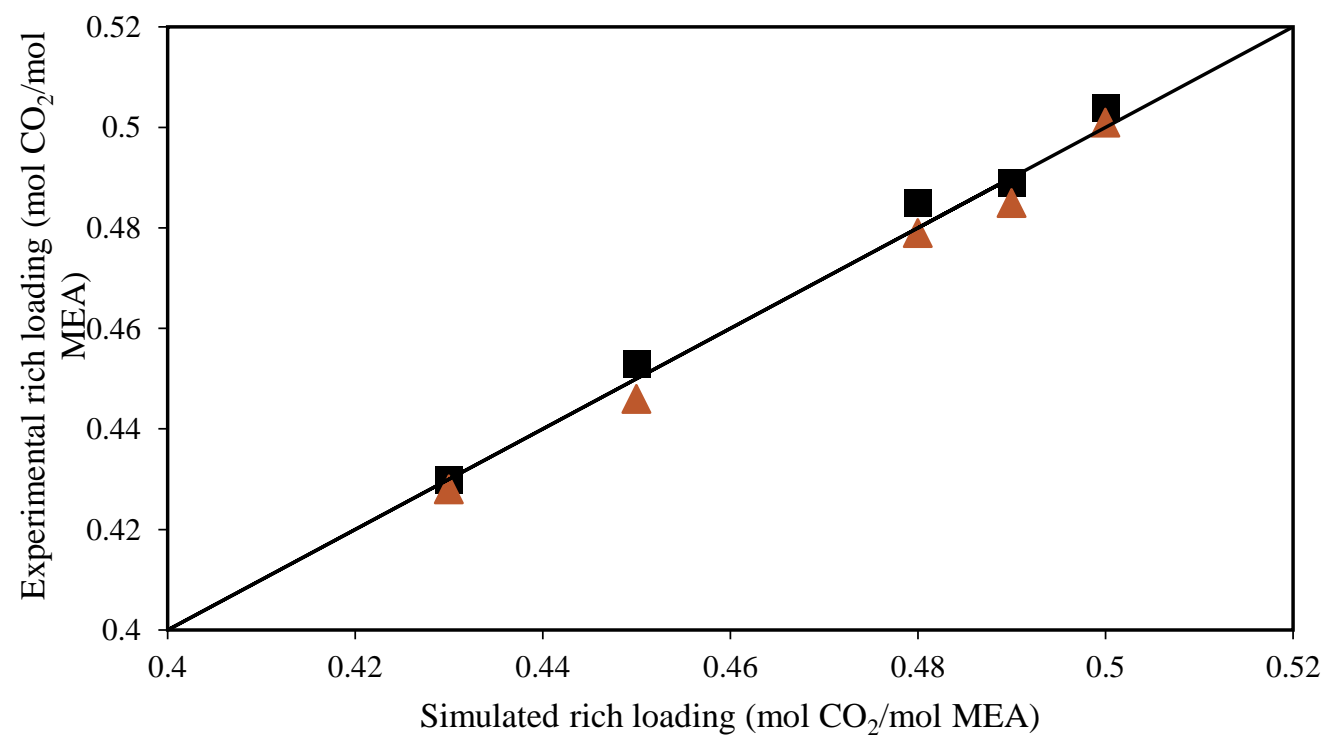


316 Fig. 2. Experimental values of rich loading (Enaasen, 2015) compared to simulated values 317 obtained with set 1 packing ( $\mathbf{\square})$ and set 2 packing ( $(\Delta)$ and the dark line represents equal 318 experimental and simulated rich loadings.

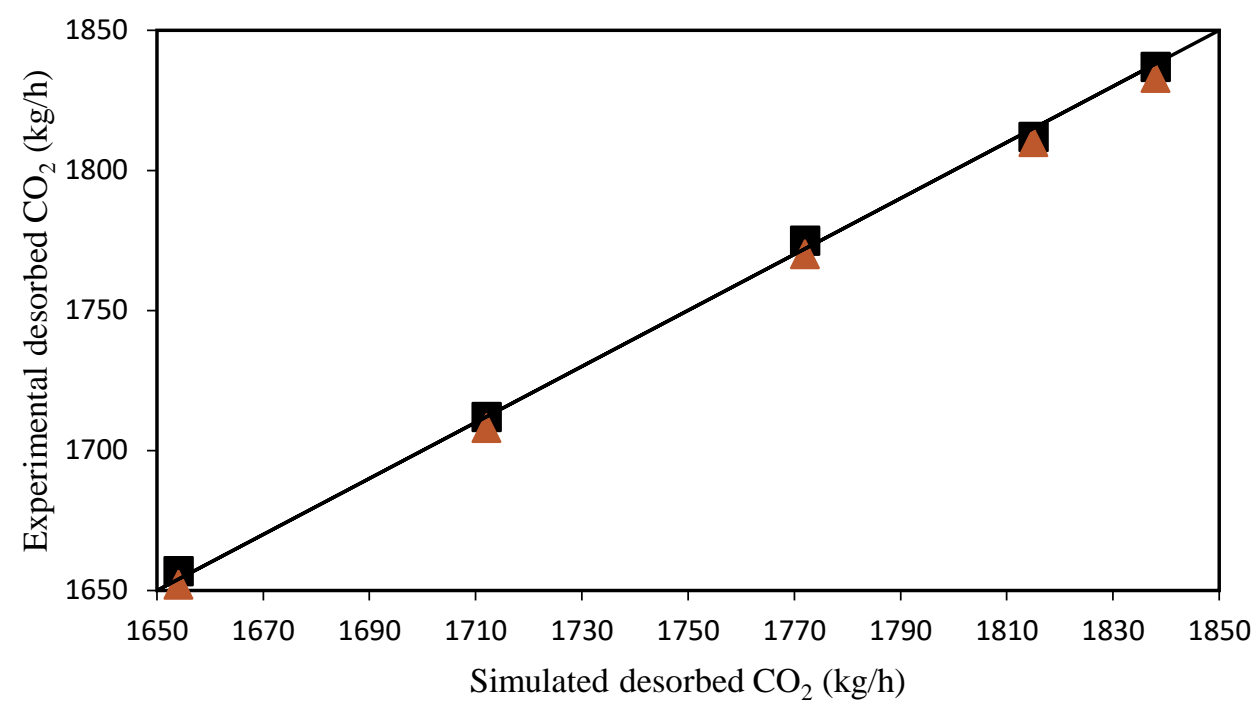

320 Fig. 3. Experimental values of desorbed $\mathrm{CO}_{2}$ (Enaasen, 2015) compared to simulated values 321 obtained with set 1 packing ( $\boldsymbol{\square}$ ) and set 2 packing ( $\Delta)$. The dark line represents equal 322 experimental and simulated desorbed $\mathrm{CO}_{2}$.

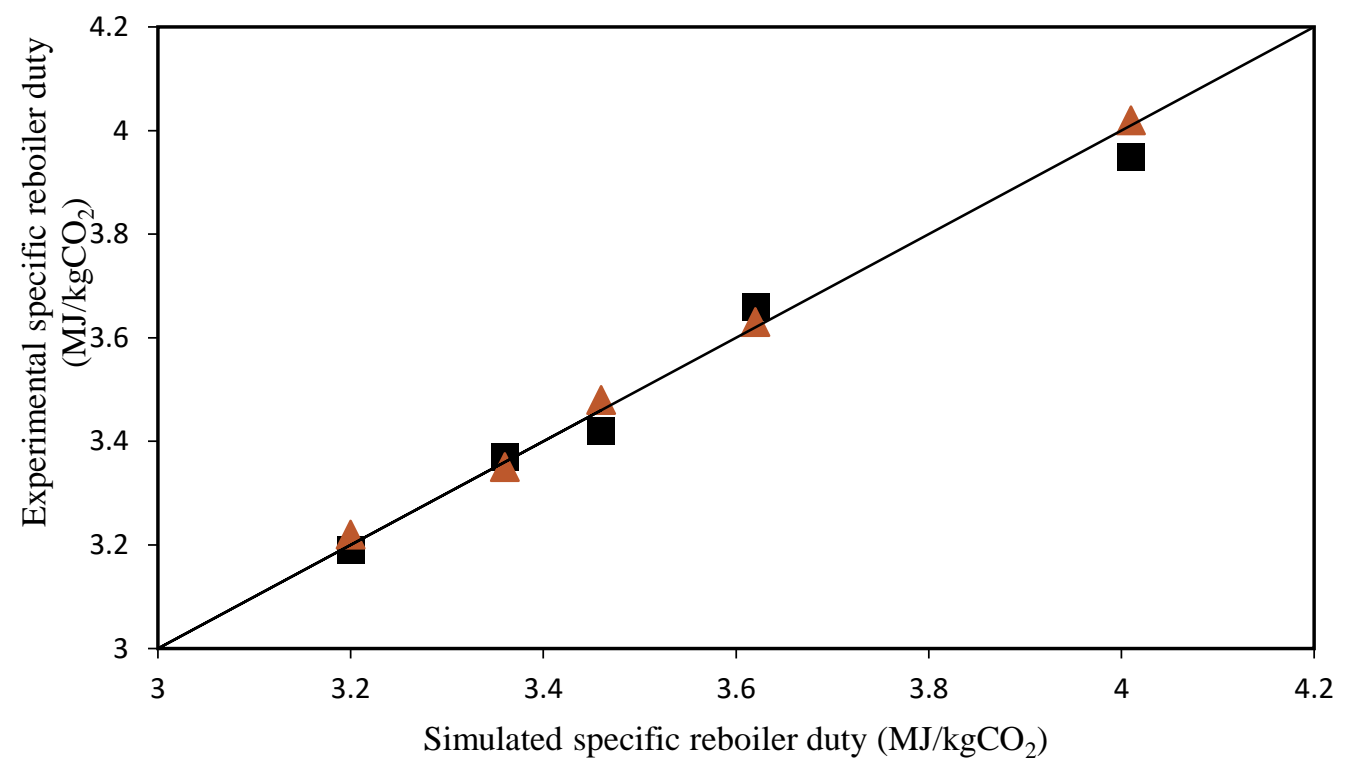

325 Fig. 4. Experimental values of specific duty (Enaasen, 2015) compared to simulated values 326 obtained with set 1 packing ( $\square)$ and set 2 packing $(\Delta)$, the dark line represents equal experimental and simulated specific duty. 


\section{A newly proposed method for estimating the diameter of absorber and stripper}

330

331

332

333

334

335

336

337

338

339

340

341

342

343

344

345

346

The diameter of a packed column is a key parameter that must be determined in the design of a packed bed absorber or stripper. The columns are designed in such a way to avoid flooding because flooding reduces their efficiency and sometimes causes the column to breakdown (Liu et al., 2019). Since the flooding point establishes the upper limit of the hydrodynamic capacity at which the packed column can operate, the velocity of the gas at flooding condition is particularly important and is a vital design parameter for the packed column (Brunazzi et al., 2008). Sherwood et al. (1938) developed the first generalized correlation chart for predicting flooding points in random dumped packings using experimental data from an air-water system. The chart which contained only one curve was later modified by Lobo et al. (1945). The ordinate of the chart includes the ratio $a / \varepsilon^{3}$ for characterising the packing size and shape. Leva (1954) added several isobaric curves to determine the pressure drop in the packed beds. In addition, Leva (1954) determined that the ratio $a / \varepsilon^{3}$ did not adequately predict the packing hydraulic performance and proposed the use of packing factor to characterise packing size and shape. Eckert (1970) further modified the chart and calculated the packing factor from experimentally determined pressure drops. The modified Eckert version (Fig. 5), known as the Sherwood-Leva-Eckert (SLE) GPDC chart has been the standard for pressure drop and flooding points prediction in a column packed with random packings for many decades.

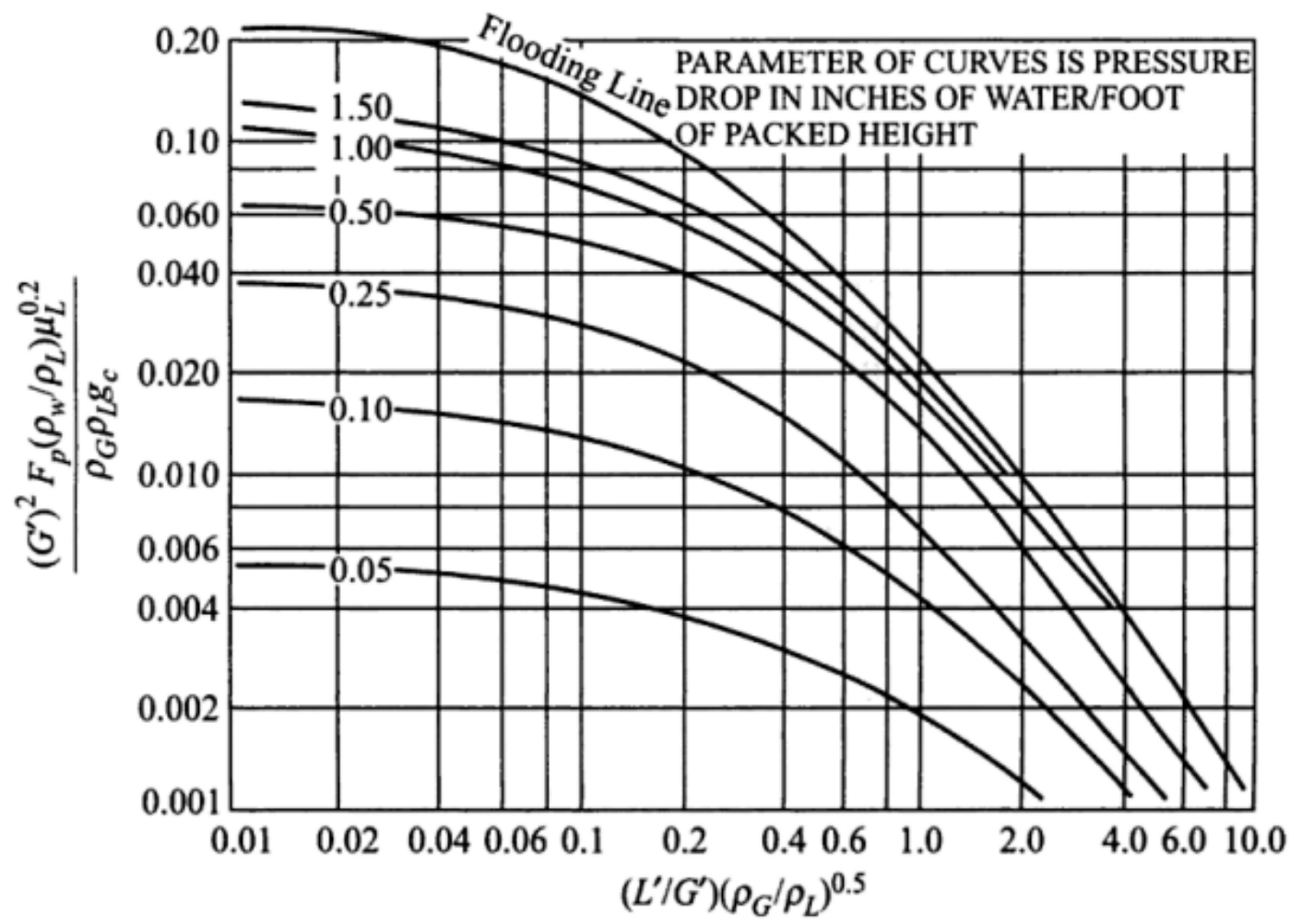


349

350

351

352

353

354

355

356

In later versions of the GPDC chart developed by Strigle (1994) for random packings and Kister et al. (2007) for structured packings, only the pressure drop curves were retained while the flooding curve was omitted (Wolf-Zöllner et al., 2019). Kister and Gill (1991) developed a correlation for predicting the flooding point and pressure drop in packed columns and an expression for the flooding curve was written in equation form particularly for the relationship between the abscissa and the ordinate as follows (Piché et al., 2001).

$$
\mathrm{CP}=\mathrm{A} \log ^{2}\left(\mathrm{~F}_{\mathrm{LV}}\right)+\mathrm{B} \log \left(\mathrm{F}_{\mathrm{LV}}\right)+\mathrm{C}
$$

Where $F_{L V}$ is the flow parameter. It is the ratio of the kinetic energy of the liquid to the kinetic energy of the gas entering the packed column (Kister et al., 2007), and it is represented as follows:

$$
\mathrm{F}_{\mathrm{LV}}=\frac{\mathrm{L}}{\mathrm{G}} \sqrt{\frac{\rho_{\mathrm{L}}}{\rho_{\mathrm{G}}}}
$$

The value of the flow parameter is low for vacuum operation but high for operations involving high pressures or high liquid/vapour loading such as gas absorption operation. The CP in Eq. 5 is the capacity parameter and it is given by:

$$
\mathrm{CP}=\sqrt{\mathrm{V}_{\mathrm{G}, \mathrm{fl}}^{2}\left(\frac{\rho_{\mathrm{G}}}{\rho_{\mathrm{L}}-\rho_{\mathrm{G}}}\right) v^{0.1} \mathrm{~F}_{\mathrm{P}}}
$$

The pressure drop at which incipient flooding occurs in columns packed with modern random packings has been correlated and expressed as a function of the packing factor $F_{p}$ by Kister and Gill (1991) as shown by Eq. 8 .

$$
\Delta \mathrm{P}_{\mathrm{fl}}=0.115 \mathrm{~F}_{\mathrm{P}}^{0.7}
$$

Eq.8 also applies to structured packings and has been found to predict very well the pressure drop at flooding point for structured packings (Geankoplis, 2014; Kister and Gill, 1992). The equation is particularly applicable to packings with $F_{P}$ between 10 and $60 \mathrm{ft}^{-1}$, thus, it is capable of predicting the pressure drop at flooding in packed columns from as low as 0.57 in. $\mathrm{H}_{2} \mathrm{O} / \mathrm{ft}$ 
for packings with $\mathrm{F}_{\mathrm{p}}$ of $10 \mathrm{ft}^{-1}$ to as high as approximately 2 in. $\mathrm{H}_{2} \mathrm{O} / \mathrm{ft}$ for packings with $\mathrm{F}_{\mathrm{P}}$ of $60 \mathrm{ft}^{-1}$. However, the equation only gives an optimistic prediction of the flooding point pressure drop at $\mathrm{F}_{\mathrm{p}}$ beyond $60 \mathrm{ft}^{-1}$ and should therefore not be used with $\mathrm{F}_{\mathrm{P}}$ above this value (Geankoplis, 2014).

The expressions for determining the parameters A, B and C in Eq.5 together with their range of application are summarised in Table 7. These parameters are determined using the flooding point pressure drop calculated from Eq. 8.

\section{Table 7}

Expressions for parameters in Eq.5 (Piché et al., 2001)

\begin{tabular}{|l|c|l|}
\hline Parameters & Expression & Range of application \\
\hline A & $0.07 \ln \left(\Delta \mathrm{P}_{\mathrm{fl}}\right)-0.11$ & $0.5 \leq \Delta \mathrm{P}_{\mathrm{fl}} \leq 5.0 \mathrm{inH}_{2} \mathrm{O} / \mathrm{ft}$ \\
\hline B & $-0.25 \ln \left(\Delta \mathrm{P}_{\mathrm{fl}}\right)-0.89$ & $0.5 \leq \Delta \mathrm{P}_{\mathrm{fl}} \leq 1.0 \mathrm{inH}_{2} \mathrm{O} / \mathrm{ft}$ \\
\hline B & -0.89 & $1.0 \leq \Delta \mathrm{P}_{\mathrm{fl}} \leq 5.0 \mathrm{inH}_{2} \mathrm{O} / \mathrm{ft}$ \\
\hline C & $0.12 \ln \left(\Delta \mathrm{P}_{\mathrm{fl}}\right)+0.71$ & $0.5 \leq \Delta \mathrm{P}_{\mathrm{fl}} \leq 5.0 \mathrm{inH}_{2} \mathrm{O} / \mathrm{ft}$ \\
\hline
\end{tabular}

Eq. 5 can be re-written in the form shown below;

$$
\mathrm{CP}=\mathrm{A}\left(\log \mathrm{F}_{\mathrm{LV}}\right)^{2}+\mathrm{B} \log \left(\mathrm{F}_{\mathrm{LV}}\right)+\mathrm{C}
$$

By equating Eqs. 7 and 9 and substituting for $F_{L V}$ in the resulting equation. An expression of the form in Eq 10 can be written for the flooding velocity $\left(\mathrm{V}_{\mathrm{G}, \mathrm{fl}}\right)$.

$$
\mathrm{V}_{\mathrm{G}, \mathrm{fl}}=0.3048\left[\left(\frac{\rho_{\mathrm{G}}}{\rho_{\mathrm{L}}-\rho_{\mathrm{G}}}\right)^{-0.5} v^{-0.05} \mathrm{~F}_{\mathrm{P}}^{-0.5}\left\{\mathrm{~A}\left(\log \left(\frac{\mathrm{L}}{\mathrm{G}} \sqrt{\frac{\rho_{\mathrm{G}}}{\rho_{\mathrm{L}}}}\right)\right)^{2}+\mathrm{B}\left(\log \left(\frac{\mathrm{L}}{\mathrm{G}} \sqrt{\frac{\rho_{\mathrm{G}}}{\rho_{\mathrm{L}}}}\right)\right)+\mathrm{C}\right\}\right]
$$

The flooding velocity (upper limit of the rate of gas flow) in a packed column can be calculated from Eq.10 once process information such as the flow rate, density and kinematic viscosity of the individual phase are known. Also important is the packing factor. The values of the density and kinematic viscosity can be obtained from open literature, experiments or chemical process simulation software such as Aspen Plus ${ }^{\circledR}$ and ProMax. Eq. 10 has limitation over the range of its application. This is because the correlation presented in Eq. 8 which formed the basis of the equation only gives a good prediction of the flooding point pressure drop between Fp range of 
401

402 403

404

405

406

407

408

409

410

411

412

413

414

415

416

417

418

419

10 to $60 \mathrm{ft}^{-1}$. Therefore, it is recommended that it should only be used to estimate the flooding velocity in a column packed with packings with $\mathrm{F}_{\mathrm{P}}$ in the range specified above.

The diameter required by a given gas and liquid flow rate in a packed column is based on the maximum allowable pressure drop and the maximum operational capacity (MOC). The values for the MOC can range from 60 to 86 percent, thus, packed columns are usually designed to operate at about 60-80 percent of the flooding velocity(Marx-Schubach and Schmitz, 2019). In this work, it is assumed that the column operates at 70 percent of the flooding velocity, hence the superficial gas velocity at operating condition was calculated as follows:

$$
\mathrm{V}_{\mathrm{G}}=0.7 \mathrm{~V}_{\mathrm{G} . \mathrm{fl}}
$$

The diameter of the column required to perform the absorption operation at $70 \%$ of flooding velocity can be calculated from the expression in Eq. 12 .

$$
D=\sqrt{\frac{4 G}{\pi V_{G} \rho_{G}}}
$$

\section{Model Scale-up}

The design of a commercial PCC plant by the scale-up of PCC pilot plant model requires scaleup calculations to be performed to determine the size of the absorber and the stripper. One important parameter that determines the size of these columns is the amount of flue gas to be treated by the commercial PCC plant. In most cases, the flue gas is thousands of times the amount at pilot scale. For instance, the commercial PCC plant designed by Lawal et al. (2012) and Canepa et al. (2013) process about 5000 and 2200 times the amount of flue gas at the pilot scale. Considering that the $\mathrm{CO}_{2}$ capture process generally involves many interacting variables, accurate scale-up of the process to a commercial PCC plant that is capable of processing flue gas that is thousands of times the amount at pilot scale is, therefore, a very complicated exercise. To avoid this complication, a two-stage scale-up of the validated models presented in section 3 is carried out as follows:

(1) The validated model of the SRP $\mathrm{CO}_{2}$ capture pilot plant (flue gas flow rate $0.15 \mathrm{~kg} / \mathrm{s}$ ) is scaled up to the size of the Brindisi $\mathrm{CO}_{2}$ capture pilot plant (flue gas flow rate 3.22 $\mathrm{kg} / \mathrm{s}$ ) to validate the proposed scale-up method. 
(2) The validated model of the Brindisi pilot plant is scaled up to a commercial $\mathrm{CO}_{2}$ capture plant capable of serving a $250 \mathrm{MW}_{\mathrm{e}}$ CCGT power plant producing $356 \mathrm{~kg} / \mathrm{s}$ of flue gas.

\subsection{Scale-up of the SRP $\mathrm{CO}_{2}$ capture pilot plant to the Brindisi $\mathrm{CO}_{2}$ capture pilot plant}

In order to validate the approach proposed in section 4, the SRP pilot plant is scaled up to the size of the Brindisi pilot plant. Based on the amount of flue gas processed, the Brindisi pilot plant has the capacity that is about 22 times of the SRP pilot plant. It is a relatively large PCC pilot plant that is attached to a full-scale coal-fired power plant and operated on flue gas from the power plant. The steps involved in the scale-up calculations are provided in the following subsections:

\subsubsection{Estimation of lean solvent flow rate}

The lean solvent flow rate required to capture $90 \%$ of the $\mathrm{CO}_{2}$ in the flue gas entering the absorber of the Brindisi pilot plant is estimated based on the absorption capacity of $0.2 \mathrm{~mol}$ $\mathrm{CO}_{2} / \mathrm{mol} \mathrm{MEA}$, lean solvent MEA concentration of $30 \mathrm{wt} \%, \mathrm{CO}_{2}$ mass fraction of 0.1608 and flue gas mass flow rate of $3.22 \mathrm{~kg} / \mathrm{s}$. The estimation is carried out by assuming a constant flow rate for the gas and the solvent throughout the absorber column. The lean solvent flow rate required for the absorption operation is estimated using the approach of Agbonghae et al. (2014) presented in Eq. 13.

$$
L_{\text {Lean }}=\frac{G x_{\mathrm{CO}_{2}} \varphi_{\mathrm{CO}_{2}}}{100 z\left(\alpha_{\text {Rich }}-\alpha_{\text {Lean }}\right)}\left[\frac{M_{M E A}}{44.009}\left(1+\frac{1-\omega_{M E A}}{\omega_{M E A}}\right)+z \alpha_{\text {Lean }}\right]
$$

With regard to the stripper, the total solvent flow is equivalent to the sum of the mass flow rate of the rich solvent and reflux rate while the gas flow rate is equivalent to the boil-up rate needed to maintain the $\mathrm{CO}_{2}$ loading in the lean solvent at $0.23 \mathrm{CO}_{2} /$ per mole MEA. Based on these calculations, the solvent flow rate to the absorber and stripper was estimated to be $10.88 \mathrm{~kg} / \mathrm{s}$ and $11.5 \mathrm{~kg} / \mathrm{s}$ respectively. The gas (vapour) phase required for the desorption of $\mathrm{CO}_{2}$ was estimated to be $1.62 \mathrm{~kg} / \mathrm{s}$.

\subsubsection{Estimation of columns diameter}


The diameter of the absorber and the stripper is estimated using Eqs. 10 to 12 presented in section 4. Information regarding the density and kinematic viscosity of the MEA solvent was obtained from the SRP pilot plant model. Column packings used in the SRP pilot plant were adopted in the Brindisi plant. The absorber was packed with IMTP 40 with FP of $78.7 \mathrm{~m}^{-1}(24$ $\left.\mathrm{ft}^{-1}\right)$ and the stripper was packed with Flexipac $1 Y$ with $\mathrm{F}_{\mathrm{P}}$ of $168.3 \mathrm{~m}^{-1}\left(51.3 \mathrm{ft}^{-1}\right)$. Using the given flue gas and the estimated solvent flow rates together with the values of parameters provided in Table 8, the superficial gas velocities in the absorber and the stripper were estimated from the flooding gas velocity as 1.83 and $1.20 \mathrm{~m} / \mathrm{s}$ respectively.

\section{Table 8}

457 Parameters used to estimate the flooding velocity in the absorber and the stripper

\begin{tabular}{|l|l|l|}
\hline Parameter & Absorber & Stripper \\
\hline$\rho_{L}\left(\mathrm{~kg} / \mathrm{m}^{3}\right)$ & 1017.06 & 1019.88 \\
\hline$\rho_{G}\left(\mathrm{~kg} / \mathrm{m}^{3}\right)$ & 1.03 & 1.02 \\
\hline A & -0.11 & -0.07 \\
\hline B & -0.91 & -0.89 \\
\hline C & 0.72 & 0.79 \\
\hline
\end{tabular}

Based on the gas velocities, the diameter of the absorber and the stripper were calculated from Eq. 12 to be $1.46 \mathrm{~m}$ and $1.28 \mathrm{~m}$ respectively. The values obtained for the absorber and the stripper diameter are similar to the values of $1.5 \mathrm{~m}$ and $1.3 \mathrm{~m}$ reported for the absorber and the stripper of the Brindisi pilot plant. The percentage deviations of the estimated column diameters from those of the Brindisi pilot plant are $2.6 \%$ and $1.54 \%$, which are within an acceptable range. The fact that the method proposed herein is able to estimate the diameter of the absorber and the stripper of an existing plant validates the approach and demonstrates that it can confidently be used to estimate the diameter of a column required for an absorption process.

\subsubsection{Estimation of packing height}

The height of packing $\left(\mathrm{Z}_{\mathrm{T}}\right)$ require for a given separation in a packed column is most often expressed in terms of the overall gas-phase mass transfer coefficient and the gas composition.

471 Based on this, the packing height of the column can be calculated with the expression (Seader 472 et al., 2006). 


$$
Z_{T}=\frac{G_{i}}{K_{G} a P} \int_{y_{C o_{2, \text { in }}}}^{y_{C o_{2, \text { out }}}} \frac{d y}{y-y^{*}}
$$

473 The right-hand side of Eq.14 can be written more conveniently as a product of two terms

474 involving the height and number of transfer units.

$$
Z_{T}=H_{O G} \cdot N_{O G}
$$

475 The $\mathrm{N}_{\mathrm{OG}}$ is the number of (gas) transfer units and can be expressed as:

$$
N_{O G}=\int_{y_{C \boldsymbol{O}_{2, \text { in }}}}^{\boldsymbol{y}_{\mathrm{Co}_{2, \text { out }}}} \frac{d y}{y-y^{*}}=\operatorname{In}\left(\frac{y_{\mathrm{CO}_{2, \text { in }}}}{y_{\mathrm{CO}_{2, \text { out }}}}\right)
$$

476 The larger the value of $\mathrm{N}_{\mathrm{OG}}$, the higher the height of the packed column needed to achieve the 477 required separation. Eq. 16 assumes that the term $y^{*}$ which is the concentration of $\mathrm{CO}_{2}$ in equilibrium with the bulk concentration is negligible because of the fast reaction between $\mathrm{CO}_{2}$ and the MEA solution and because of the negligible equilibrium partial pressure of $\mathrm{CO}_{2}$ (Aroonwilas and Veawab, 2004; Fu et al., 2014; Khan et al., 2011).

The $\mathrm{H}_{\mathrm{OG}}$ is the height of a transfer unit, it shows the efficiency of the packing i.e. the smaller the value of $\mathrm{H}_{\mathrm{OG}}$ the more efficient the contacting (Coulson and Richardson, 2002). The value of HoG was computed by:

$$
H_{O G}=\frac{G_{i}}{K_{G} a P}
$$

Dugas (2006) in a series of experiments performed at the SRP pilot plant reported the mass transfer performance of the packing (IMTP 40) in terms of $\mathrm{K}_{\mathrm{G}} \mathrm{a}$ in the absorber used to absorb $\mathrm{CO}_{2}$ from the flue gas using MEA. The concentrations of the MEA in the solvent and $\mathrm{CO}_{2}$ in the flue gas, as well as the operating conditions i.e. temperature and pressure used to obtain the $\mathrm{K}_{\mathrm{G}} \mathrm{a}$ values are similar to that of the Brindisi pilot plant. Considering that the same packing is used in the Brindisi pilot plant, the $\mathrm{K}_{\mathrm{G}}$ a values are not expected to change markedly. In view of this, the $\mathrm{K}_{\mathrm{G}}$ a values reported by Dugas (2006) were used to estimate the HoG of the absorber. 
497

498

499

500

501

502

503

504

505

506

507

508

509

510

511

512

513

514

515

Based on the above, the packing height $\left(\mathrm{Z}_{\mathrm{T}}\right)$ of the absorber was estimated to be $22.55 \mathrm{~m}$ using the values of the parameters summarised in Table 9.

\section{Table 9}

Calculated values of parameters used to estimate the absorber packed bed

\begin{tabular}{|c|c|}
\hline Parameters & Value \\
\hline $\mathrm{N}_{\mathrm{OG}}$ & 4.1 \\
\hline $\mathrm{K}_{\mathrm{Ga}}\left(\mathrm{kmol} / \mathrm{m}^{3} \mathrm{~s}\right.$. bar $)$ & $1.22 \times 10^{-2}$ \\
\hline $\mathrm{G}_{\mathrm{i}}\left(\mathrm{kmol} / \mathrm{s} \mathrm{m}^{2}\right)$ & 0.06 \\
\hline $\mathrm{P}(\mathrm{bar})$ & 1.00 \\
\hline $\mathrm{H}_{\mathrm{OG}}(\mathrm{m})$ & 5.50 \\
\hline
\end{tabular}

The packing height of the stripper could not be determined using the same approach for the absorber because the $\mathrm{K}_{\mathrm{G}}$ a values for the runs with the Flexipac $1 \mathrm{Y}$ in the stripper were not reported (Dugas, 2006). During the experiments, negative $\mathrm{CO}_{2}$ driving force was encountered at the top of the stripper, that made it impossible to calculate the log mean driving force and the mass transfer coefficient of the Flexipac 1Y packing. Therefore, the packing height of the stripper was determined using a different approach that involves the summation of the HETPs of stages in the stripper. This is the same approach used in Agbonghae et al. (2014) to estimate the stripper packing height. The packing height of a stripper with $\mathrm{N}$ number of stages can be estimated as follows; (Agbonghae et al., 2014).

$$
Z_{T, \text { Stripper }}=\sum_{i=2}^{N-1} H E T P_{i}
$$

The approach was implemented using the calculator block in Aspen Plus ${ }^{\circledR}$ to automatically adjust the ending stage number of the packed section to the number of stages while fixing the starting stage of the packed section. The starting stage for the stripper was fixed at 2 , also a design specification for the lean loading was set at $0.23 \mathrm{~mol} \mathrm{CO} / \mathrm{mol} \mathrm{MEA}$. Starting with a generic total stage number of 5 , the number of stages in the stripper was continuously increased by 1 , till a certain point where a further increase had a negligible effect on the reboiler duty. Using this approach, the packing height of the stripper was determined to be $11.4 \mathrm{~m}$. Details of this approach can be obtained is available in Agbonghae et al. (2014). Table 10 shows how the 
scale-up result for the diameter and packing height of the absorber and stripper compare with

517 the pilot plant.

518 Table 10

519 Comparison of results between the scale-up and the pilot plant measurement

520

\begin{tabular}{|l|l|l|l|l|}
\hline \multirow{2}{*}{} & \multicolumn{2}{|c|}{ Pilot plant } & \multicolumn{2}{c|}{ Scale-up } \\
\cline { 2 - 6 } & Absorber & Stripper & Absorber & Stripper \\
\hline Diameter (m) & 1.50 & 1.30 & 1.46 & 1.28 \\
\hline Height (m) & 22 & 11 & 22.55 & 11.40 \\
\hline
\end{tabular}

\section{1}

\subsection{Scale-up of the Brindisi $\mathrm{CO}_{2}$ capture plant to commercial $\mathrm{CO}_{2}$ capture plant}

522 Having applied the approach to scale-up between existing capture plants in section 5.1, the

523 Brindisi $\mathrm{CO}_{2}$ capture plant was scaled up to deal with the flue gas equivalent to that discharge 524 by a $250 \mathrm{MW}_{\mathrm{e}}$ CCGT power plant described in Canepa et al. (2013). Based on the amount of 525 flue gas processed, the capacity of the commercial $\mathrm{CO}_{2}$ capture plant is about 110 times that of 526 the Brindisi $\mathrm{CO}_{2}$ capture plant. The operating conditions of the columns and the input 527 conditions of the flue gas after treatment to remove acid gases, oxygen and particulates matter 528 are given in Table 11. These conditions were chosen to be the same as those reported for the 529 case without exhaust gas recirculation in Canepa et al. (2013). This was done to enable the 530 comparison of results obtained from this study with those obtained from that study Canepa et 531 al. (2013) who had previously scaled up from the SRP pilot plant based on these same 532 conditions using the GPDC method and assumed pressure drop of $412 \mathrm{~Pa} / \mathrm{m}$ of packing.

\section{Table 11}

534 Inlet conditions of the PCC capture plant (Canepa et al., 2013)

\begin{tabular}{|l|l|}
\hline Compositions (Mass fraction) & Value \\
\hline $\mathrm{CO}_{2}$ & 0.076 \\
\hline $\mathrm{H}_{2} \mathrm{O}$ & 0.047 \\
\hline $\mathrm{N}_{2}$ & 0.862 \\
\hline Argon & 0.015 \\
\hline Flue gas temperature (K) & 313 \\
\hline Lean solvent temperature & 313 \\
\hline Lean MEA concentration (wt\%) & 30 \\
\hline $\mathrm{CO}_{2}$ Capture level $(\%)$ & 90 \\
\hline Mass flow rate $(\mathrm{kg} / \mathrm{s})$ & 356 \\
\hline Absorber pressure $(\mathrm{kPa})$ & 101 \\
\hline Absorber packing type & IMTP no. 40 \\
\hline
\end{tabular}




\begin{tabular}{|l|l|}
\hline Stripper pressure $(\mathrm{kPa})$ & 162 \\
\hline Stripper packing type & Flexipac $1 \mathrm{Y}$ \\
\hline
\end{tabular}

535

536

537

538

539

540

541

542

543

Going by the $\mathrm{CO}_{2}$ mass fraction, flue gas mass flow rate, lean MEA concentration and the $\mathrm{CO}_{2}$ capture level in Table 11, the solvent flow rate required by the commercial $\mathrm{CO}_{2}$ capture plant to treat the flue gas was estimated with Eq. 13. The amount of solvent flow required is dependent on its absorption capacity. The impact of the absorption capacity $(\Delta \alpha)$ on the solvent flow rate required by the commercial $\mathrm{CO}_{2}$ capture plant is shown in Fig. 6. The solvent flow rate to the absorber was estimated to be $669 \mathrm{~kg} / \mathrm{s}$. Likewise, the solvent flow rate to the stripper was obtained to be $583 \mathrm{~kg} / \mathrm{s}$ while the vapour flow rate (boiled-up rate) was obtained to be 58 $\mathrm{kg} / \mathrm{s}$.

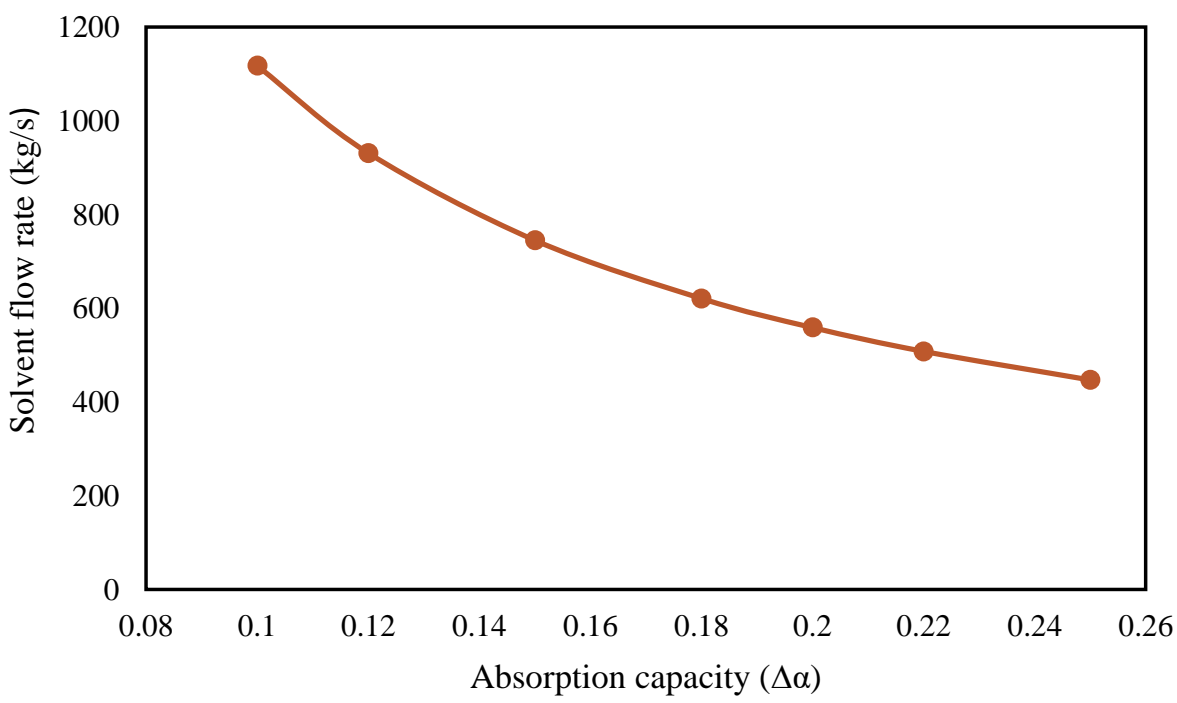

544

545

546

547

548

549

550

551

552

553

554

555

556

Fig. 6 Solvent flow rate at different absorption capacity

The diameter of the absorber and the stripper required by the commercial $\mathrm{CO}_{2}$ capture plant were determined as earlier illustrated in section 5.1.2 using Eqs. 10 - 12. Physical properties such as density and kinematic viscosity useful for calculation were obtained from the Brindisi $\mathrm{CO}_{2}$ capture pilot plant model simulation. The flooding velocity $\left(\mathrm{V}_{\mathrm{G}, \mathrm{fl}}\right)$ and the operating superficial gas velocity $\mathrm{V}_{\mathrm{G}}$ were determined to be $3.25 \mathrm{~m} / \mathrm{s}$ and $2.27 \mathrm{~m} / \mathrm{s}$ in the absorber, and $1.83 \mathrm{~m} / \mathrm{s}$ and $1.28 \mathrm{~m} / \mathrm{s}$ in the stripper respectively. The vapour flow rate was far lower in the stripper than in the absorber thereby making the rich amine flow rate the deciding factor in the design, hence a smaller diameter than the absorber.

Based on the superficial gas velocities in the columns, the diameter of the absorber and the stripper required by the commercial $\mathrm{CO}_{2}$ capture plant was determined to be $13.86 \mathrm{~m}$ and 7.50 $\mathrm{m}$ respectively. The relationship between the diameter and the number of columns required by 
the capture plant is presented in Fig. 7. This was based on what can be delivered by the stateof-the-art technology and maximum column diameter of $18 \mathrm{~m}$ for a commercial $\mathrm{CO}_{2}$ capture plant (IEA-GHG, 2006; Reddy et al., 2013, 2008; Scherffius et al., 2013). Moreover, absorbers of similar diameter have been designed and built by Fluor just as strippers of similar diameter have been constructed and used for $\mathrm{SO}_{2}$ stripping in power plants (Dutta et al., 2017; Reddy et al., 2008).

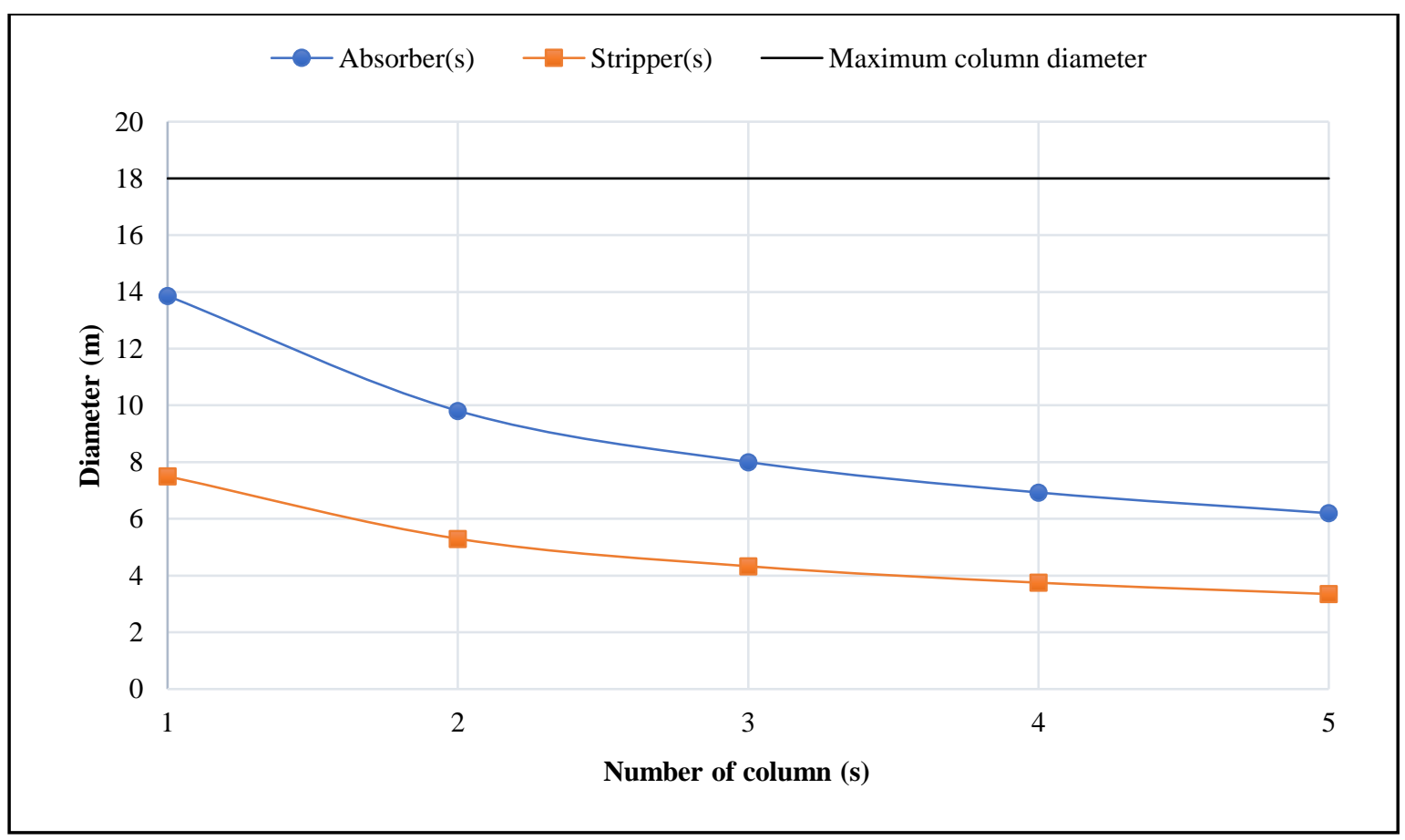

Fig. 7 Relationship of the diameter of columns and the number of columns

The diameter calculated for the absorber and the stripper in this study was found to be below this value. As a result, a single absorber and a single stripper were selected for the commercialscale $\mathrm{CO}_{2}$ capture plant in order to minimize the number of absorption trains and reduce the complexity of the plant. As a consequence, the plant footprint and capital cost are reduced. The packing height of $28.5 \mathrm{~m}$ was arrived at for the absorber using the approach presented in section

\section{Simulation of the commercial $\mathrm{CO}_{2}$ capture plant}


The commercial-scale $\mathrm{CO}_{2}$ capture plant was simulated in Aspen Plus ${ }^{\circledR}$ V8.4 and the flowsheet that was developed for the plant in this work is shown in Fig. 8. The comparison of results obtained from the final simulation with Canepa et al. (2013) is presented in Table 12.

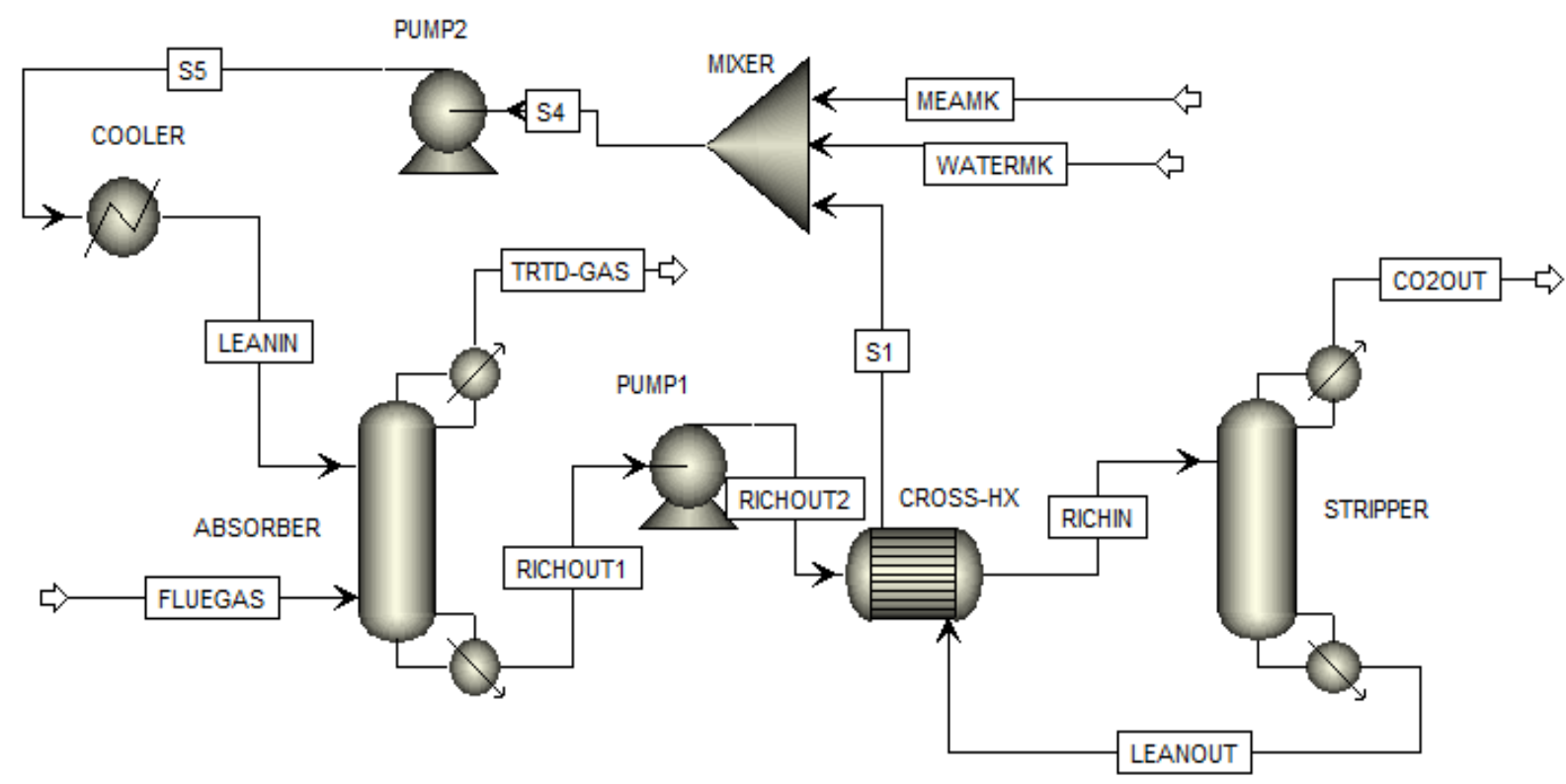

579

Fig. 8 Process flowsheet of the commercial $\mathrm{CO}_{2}$ in Aspen Plus ${ }^{\circledR}$

It can be observed from Table 12 that this study achieves lesser equipment size than those reported in Canepa et al. (2013) for the absorber and the stripper columns. In Canepa et al. (2013), two absorbers each of diameter $9.5 \mathrm{~m}$ and a stripper of diameter $8.2 \mathrm{~m}$ were required by the $\mathrm{CO}_{2}$ capture plant to treat flue gas from a $250 \mathrm{CCGT}$ power plant. In this study, a single absorber and stripper of diameters $13.86 \mathrm{~m}$ and $7.5 \mathrm{~m}$ respectively were designed for the same capture plant. The higher column diameter reported by Canepa et al. (2013) might be due to the pressure drop of $412 \mathrm{~Pa} / \mathrm{m}$ packing assumed in columns sizing is higher than the actual pressure drop in the absorber and the stripper of a $\mathrm{CO}_{2}$ capture plant for a 250 CCGT power plant.

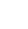


596 Comparison of key results obtained from this work with those obtained by Canepa et al. (2013)

\begin{tabular}{|l|l|l|}
\hline & Canepa et al. (2013) & Results from this work \\
\hline Lean solvent flow rate $(\mathrm{kg} / \mathrm{s})$ & 720.46 & 705.23 \\
\hline $\mathrm{L} / \mathrm{G}$ ratio $(\mathrm{mol} / \mathrm{mol})$ & 2.29 & 2.23 \\
\hline Lean solvent loading $\left(\mathrm{mol} \mathrm{CO}_{2} / \mathrm{mol} \mathrm{MEA)}\right)$ & 0.30 & 0.30 \\
\hline Rich solvent loading $\left(\mathrm{mol} \mathrm{CO}_{2} / \mathrm{mol} \mathrm{MEA}\right)$ & 0.45 & 0.47 \\
\hline $\mathrm{CO}_{2}$ capture level $(\%)$ & 90 & 90 \\
\hline Flooding ratio $(\%)$ & Not reported & 70 \\
\hline
\end{tabular}

Absorber

\begin{tabular}{|l|l|l|}
\hline Number of absorbers & $2^{\mathbf{a}}$ & 1 \\
\hline Absorber packing & IMTP no. 40 & IMTP no. 40 \\
\hline Absorber diameter $(\mathrm{m})$ & 9.50 & 13.86 \\
\hline Absorber packing height $(\mathrm{m})$ & 30 & 28.50 \\
\hline Absorber pressure drop $(\mathrm{Pa} / \mathrm{m})$ & 412 & 241 \\
\hline
\end{tabular}

Stripper

Number of strippers

Stripper diameter $(\mathrm{m})$

Stripper packing height $(\mathrm{m})$

Stripper pressure drop $(\mathrm{Pa} / \mathrm{m})$

Reboiler temperature $\left({ }^{\circ} \mathrm{C}\right)$

Reboiler duty (MW)

Specific duty $\left(\mathrm{GJ} /\right.$ tonCO $\left.\mathrm{CO}_{2}\right)$

Condenser temperature $\left({ }^{\circ} \mathrm{C}\right)$

\begin{tabular}{|l|l|}
\hline 1 & 1 \\
\hline 8.20 & 7.50 \\
\hline 30 & 28.50 \\
\hline 412 & 57 \\
\hline 117 & 115.70 \\
\hline 121 & 115.30 \\
\hline 4.97 & 4.69 \\
\hline 25 & 25 \\
\hline
\end{tabular}

a A single absorber will result in diameter of $14.10 \mathrm{~m}$.

The commercial-scale $\mathrm{CO}_{2}$ capture developed in this study achieved a pressure drop of 241

$\mathrm{Pa} / \mathrm{m}$ and $57 \mathrm{~Pa} / \mathrm{m}$ of packing in the absorber and in the stripper respectively. The pressure drop in the stripper is much lower than the absorber because the vapour flow in the stripper is much lower and the structured packing used in the stripper is expected to provide lower gas-phase pressure drop than the random packing used in the absorber. The pressure drop in the absorber and the stripper are less for this study indicating a reduction in power loss due to pumping which would translate to a reduction in the operational costs of the capture process.

Meanwhile, the absorber and the stripper packing height in this study are also smaller. Canepa et al. (2013) reported the same packing height of $30 \mathrm{~m}$ for the absorber and the stripper in their study without giving the details of how the values were arrived at. This was despite using a structured packing (Flexipac 1Y) with higher mass transfer efficiency and lower HETP (which should reduce packing height) in the stripper. The results in this study will support more 
accurate estimation of the capital cost of the process since according to Abu-Zahra et al. (2007) the absorber and the stripper account for about $55 \%$ and $17 \%$ of the total equipment purchase cost for the whole $\mathrm{CO}_{2}$ capture process. The specific duty of the $\mathrm{CO}_{2}$ capture plant attained a value of $4.69 \mathrm{GJ} /$ ton $\mathrm{CO}_{2}$ representing a $5.63 \%$ reduction in the value reported by Canepa et al. (2013). The solvent flow rate is also less for this study because more $\mathrm{CO}_{2}$ is absorbed as reflected in the rich loading which is slightly higher in this study. The lower solvent flow rate would reduce the energy consumption for pumping and regeneration thereby reducing the operating cost of the process.

\section{Conclusions}

A steady-state model for the solvent-based post-combustion $\mathrm{CO}_{2}$ capture plant using MEA has been developed and validated at pilot scale in Aspen Plus ${ }^{\circledR}$. The validation results showed good agreement between the model predictions and the pilot plants measurements. A new scale-up method for estimating packed column diameter based on the use of flooding gas velocity is proposed in this paper. The scale-up method was validated by applying it to the scale-up between two existing pilot plant sizes. The method was able to estimate the diameter of the absorber and the stripper with deviations of $2.6 \%$ and $2.54 \%$ respectively. The validation showed that the method could be used to estimate the diameter of the packed column used in the $\mathrm{CO}_{2}$ capture process. Furthermore, it was used to scale up the validated model from pilot scale to commercial scale to process flue gas from a $250 \mathrm{MW}_{\mathrm{e}}$ CCGT power plant. The results obtained show that estimates using the GPDC method in literature may be significantly higher than required. In addition, with our approach, it was found that for commercial-scale cases, the solvent flow rate and energy consumption were less by about $2.12 \%$ and $5.63 \%$ compared to the GPDC approach. Therefore, the capital and operating costs for the process using the newly proposed scale-up method could be lower based on our estimates of the column dimensions, solvent flow rate and specific reboiler duty.

\section{Acknowledgment}

The authors would like to gratefully acknowledge the financial support received for this research from the Petroleum Technology Development Fund (PTDF), Nigeria.

\section{References}

Abu-Zahra, M.R.M., Niederer, J.P.M., Feron, P.H.M., Versteeg, G.F., 2007. $\mathrm{CO}_{2}$ capture from 
power plants. Part II. A parametric study of the economical performance based on monoethanolamine. Int. J. Greenh. Gas Control 1, 135-142.

Agbonghae, E.O., Hughes, K.J., Ingham, D.B., Ma, L., Pourkashanian, M., 2014. Optimal process design of commercial-scale amine-based CO2capture plants. Ind. Eng. Chem. Res. 53, 14815-14829.

Aroonwilas, A., Tontiwachwuthikul, P., Chakma, A., 2001. Effects of operating and design parameters on $\mathrm{CO}_{2}$ absorption in columns with structured packings. Sep. Purif. Technol. $24,403-411$.

Aroonwilas, A., Veawab, A., 2004 Characterization and Comparison of the $\mathrm{CO}_{2}$ Absorption Performance into Single and Blended Alkanolamines in a Packed Column. Ind. Eng. Chem. Res. 43, 2228-2237.

Aspen Technology, 2008. Rate-based model of the $\mathrm{CO}_{2}$ capture process by MEA using Aspen plus. Burlington, MA.

Aspen Technology, 2001. Physical property methods and models 11.1. Cambridge, MA.

Awoyomi, A., Kumar, P., Edward, A., 2019. $\mathrm{CO}_{2} / \mathrm{SO}_{2}$ emission reduction in $\mathrm{CO}_{2}$ shipping infrastructure. Int. J. Greenh. Gas Control 88, 57-70.

Biliyok, C., Yeung, H., 2013. Evaluation of natural gas combined cycle power plant for postcombustion $\mathrm{CO}_{2}$ capture integration. Int. J. Greenh. Gas Control 19, 396-405.

Bravo, J, L. Rocha, J, A. Fair, J, R., 1985. Mass transfer in Gauze Packings. Hydrocarb. Process 64, 91-95.

Bravo, J.L., Patwardhan, A.A., Edgar, T.F., 1992. Influence of Effective Interfacial Areas in the Operation and Control of Packed Distillation Columns. Ind. Eng. Chem. Res. 31, 604608.

Brunazzi, E., Macías-Salinas, R., Viva, A., 2008. Calculation Procedure for Flooding in Packed Columns Using a Channel Model. Chem. Eng. Commun. 196, 330-341.

Bui, M., Gunawan, I., Verheyen, V., Feron, P., Meuleman, E., Adeloju, S., 2014. Dynamic modelling and optimisation of flexible operation in post-combustion $\mathrm{CO}_{2}$ capture plantsA review. Comput. Chem. Eng. 61, 245-265.

Bui, M., Tait, P., Lucquiaud, M., Mac Dowell, N., 2018. Dynamic operation and modelling of amine-based $\mathrm{CO}_{2}$ capture at pilot scale. Int. J. Greenh. Gas Control 79, 134-153.

Canepa, R., Wang, M., Biliyok, C., Satta, A., 2013. Thermodynamic analysis of combined cycle gas turbine power plant with post-combustion $\mathrm{CO}_{2}$ capture and exhaust gas recirculation. Proc. Inst. Mech. Eng. Part E J. Process Mech. Eng. 227, 89-105.

Chen, C. -C, Evans, L.B., 1986. A local composition model for the excess Gibbs energy of 
aqueous electrolyte systems. AIChE J. 32, 444-454.

676

677

678

679

680

681

682

683

684

685

686

687

688

689

690

691

692

693

694

695

696

697

698

699

700

701

702

703

704

705

706

707

708

Chilton, T.H., Colburn, A.P., 1934. Mass Transfer Coefficients: Prediction from Data on Heat Transfer and Fluid Friction. Ind. Eng. Chem. 26, 1183-1187.

Coulson, J.M., Richardson, J.F., 2002. Chemical Engineering, 5th ed. Butterwoth Heinemann, Oxford.

Dugas, R., 2006. Pilot Plant Study of Carbon Dioxide Capture by Aqueous Monoethanolamine. MSE Thesis. University of Texas at Austin.

Dutta, R., Nord, L.O., Bolland, O., 2017. Selection and design of post-combustion $\mathrm{CO}_{2}$ capture process for $600 \mathrm{MW}$ natural gas fueled thermal power plant based on operability. Energy 121, 643-656.

Eckert, J.S., 1970. Selecting the Proper Distillation Column Packing. Chem. Eng. Prog. 66, 39-44.

Enaasen, F.N., Knuutila, H., Kvamsdal, H.M., Hillestad, M., 2015. Dynamic model validation of the post-combustion $\mathrm{CO}_{2}$ absorption process. Int. J. Greenh. Gas Control 41, 127-141.

Enaasen, N.F., 2015. Post-combustion absorption-based $\mathrm{CO}_{2}$ capture : modeling, validation and analysis of process dynamics. $\mathrm{PhD}$ Thesis. Norwegian University of Science and Technology.

Environmental Protection Agency, 2017. Global Greenhouse Gas Emissions Data. Available at https://www.epa.gov/ghgemissions/global-greenhouse-gas-emissions-data\%0D (accessed on 20 March 2019).

Errico, M., Madeddu, C., Pinna, D., Baratti, R., 2016. Model calibration for the carbon dioxideamine absorption system. Appl. Energy 183, 958-968.

Fu, K., Chen, G., Liang, Z., Sema, T., Idem, R., 2014. Analysis of Mass Transfer Performance of Monoethanolamine-Based $\mathrm{CO}_{2}$ Absorption in a Packed Column Using Artificial Neural Networks.

Garcia, M., Knuutila, H.K., Gu, S., 2017. Aspen Plus simulation model for $\mathrm{CO}_{2}$ removal with MEA: Validation of desorption model with experimental data. J. Environ. Chem. Eng. 5, 4693-4701.

Gaspar, J., Cormos, A.M., 2012. Dynamic modeling and absorption capacity assessment of $\mathrm{CO}_{2}$ capture process. Int. J. Greenh. Gas Control 8, 45-55.

Geankoplis, C.J., 2014. Transport Process \& Separation Process Principles (Includes Unit Operations), 4th ed. Pearson Education Limited, Essex.

Greer, T., Bedelbayev, A., Igreja, J.M., Gomes, J.F., Lie, B., 2010. A simulation study on the abatement of $\mathrm{CO}_{2}$ emissions by de-absorption with monoethanolamine. Environ. Technol. 
31, 107-115.

Harun, N., Nittaya, T., Douglas, P.L., Croiset, E., Ricardez-Sandoval, L.A., 2012. Dynamic simulation of MEA absorption process for $\mathrm{CO}_{2}$ capture from power plants. Int. J. Greenh. Gas Control 10, 295-309.

IEA-GHG, 2006. $\mathrm{CO}_{2}$ capture in low rank coal power plant. IEA Greenh. Gas R\&D Program. Rep. no2006/1.

Khan, F.M., Krishnamoorthi, V., Mahmud, T., 2011. Modelling reactive absorption of $\mathrm{CO}_{2}$ in packed columns for post-combustion carbon capture applications. Chem. Eng. Res. Des. 89, 1600-1608.

Kister, H.Z., Gill, D.R., 1992. Flooding and Pressure Drop Prediction for Structured Packings. IChemE Symp. Ser. 128 A109-A123.

Kister, H.Z., Gill, R.D., 1991. Predict Flood Point and Pressure Drop for Modern Random Packings. Chem. Eng. Prog. 87, 32-42.

Kister, H.Z., Scherffius, J., Afshar, K., Abkar, E., 2007. Realistically predict capacity and pressure drop for packed columns. Chem. Eng. Prog. 103, 28-38.

Kvamsdal, H.M., Jakobsen, J.P., Hoff, K.A., 2009. Dynamic modeling and simulation of a $\mathrm{CO}_{2}$ absorber column for post-combustion $\mathrm{CO}_{2}$ capture. Chem. Eng. Process. Process Intensif. $48,135-144$.

Lawal, A., Wang, M., Stephenson, P., Koumpouras, G., Yeung, H., 2010. Dynamic modelling and analysis of post-combustion $\mathrm{CO}_{2}$ chemical absorption process for coal-fired power plants. Fuel 89, 2791-2801.

Lawal, A., Wang, M., Stephenson, P., Obi, O., 2012. Demonstrating full-scale post-combustion $\mathrm{CO}_{2}$ capture for coal-fired power plants through dynamic modelling and simulation. Fuel $101,115-128$.

Lawal, A., Wang, M., Stephenson, P., Yeung, H., 2009. Dynamic modelling of $\mathrm{CO}_{2}$ absorption for post combustion capture in coal-fired power plants. Fuel 88, 2455-2462.

Lemaire, E., Bouillon, P.A., Lettat, K., 2014. Development of HiCapt+ TM Process for $\mathrm{CO}_{2}$ Capture from Lab to Industrial Pilot Plant. Oil Gas Sci. Technol. - Rev. d'IFP Energies Nouv. 69, 1069-1080.

Leva, M., 1954. Flow Through Irrigated Dumped Packings. Chem. Eng. Prog. 50, 51-59.

Liu, Y., Hseuh, B.F., Gao, Z., Wong, D.S.H., Yao, Y., 2019. Dynamic Profile Monitoring for Flooding Prognosis in Packed Columns. Chem. Eng. Technol. 42, 1232-1239.

Lobo, W.., Friend, L., Hashmall, H., Zenz, F.A., 1945. Limiting Capacity of Dumped Tower Packings. Trans Am. Inst. Chem. Eng. 41, 693-710. 
Luo, X., Wang, M., 2017. Improving Prediction Accuracy of a Rate-Based Model of an MEABased Carbon Capture Process for Large-Scale Commercial Deployment. Engineering 3, 232-243.

Marx-Schubach, T., Schmitz, G., 2019. Modeling and simulation of the start-up process of coal fired power plants with post-combustion $\mathrm{CO}_{2}$ capture. Int. J. Greenh. Gas Control 87, 4457.

Nittaya, T., Douglas, P.L., Croiset, E., Ricardez-Sandoval, L.A., 2014. Dynamic modeling and evaluation of an industrial-scale $\mathrm{CO}_{2}$ capture plant using monoethanolamine absorption processes. Ind. Eng. Chem. Res. 53, 11411-11426.

Onda, K., Takeuchi, H., Okumoto, Y., 1968. Mass transfer coefficients between gas and liquid phases in packed columns. J. Chem. Eng. Japan 1, 56-62.

Piché, S., Larachi, F., Grandjean, B.P.A., 2001. Loading capacity in packed towers - Database, correlations and analysis. Chem. Eng. Technol. 24, 373-380.

Pintola, T., Tontiwachwuthikul, P., Meisen, A., 1993. Simulation of pilot plant and industrial $\mathrm{CO}_{2}$-MEA absorbers. Gas Sep. Purif. 7, 47-52.

Plaza, J.M., Rochelle, G.T., 2011. Modeling pilot plant results for $\mathrm{CO}_{2}$ capture by aqueous piperazine. Energy Procedia 4, 1593-1600.

Razi, N., Svendsen, H.F., Bolland, O., 2013. Validation of mass transfer correlations for $\mathrm{CO}_{2}$ absorption with MEA using pilot data. Int. J. Greenh. Gas Control 19, 478-491.

Reddy, S., Johnson, D., Gilmartin, J., 2008. Fluor's econamine FG plus ${ }^{\mathrm{SM}}$ technology for $\mathrm{CO}_{2}$ capture at coal-fired power plants. Air Waste Manag. Assoc. - 7th Power Plant Air Pollut. Control "Mega" Symp. 2008 1, 63-79.

Reddy, S., Scherffius, J.R., Yonkoski, J., Radgen, P., Rode, H., 2013. Initial results from fluor's $\mathrm{CO}_{2}$ capture demonstration plant using econamine FG PlusSM technology at E.ON Kraftwerke's wilhelmshaven power plant. Energy Procedia 37, 6216-6225.

Rezazadeh, F., Gale, W.F., Rochelle, G.T., Sachde, D., 2017. Effectiveness of absorber intercooling for $\mathrm{CO}_{2}$ absorption from natural gas fired flue gases using monoethanolamine solvent. Int. J. Greenh. Gas Control 58, 246-255.

Scherffius, J.R., Reddy, S., Klumpyan, J.P., Armpriester, A., 2013. Large-scale $\mathrm{CO}_{2}$ capture demonstration plant using fluor's econamine FG Plus ${ }^{\mathrm{SM}}$ technology at NRG's WA parish electric generating station. Energy Procedia 37, 6553-6561.

Seader, J.D., Seider, W.D., Lewin, D.R., Boulle, L., Rycrof, A., 2006. Separation Process Principles, 3rd ed. John Wiley \& Sons, INC, Hoboken, NJ.

Sherwood, T.K., Shipley, G.H., Holloway, F.A.L., 1938. Flooding Velocities in Packed 
Columns. Ind. Eng. Chem. 30, 765-769.

Sinnott, R.K., 2005. Chemical Engineering Design, Fouth Edit. Coulson \& Richardson's Chemical Engineering series. Elsevier Butterworth-Heinemann, Oxford.

Soave, G., 1972. Equilibrium constants from a modified Redlich-Kwong equation of state. Chem. Eng. Sci. 27, 1197-1203.

Soltani, S.M., Fennell, P.S., Mac Dowell, N., 2017. A parametric study of $\mathrm{CO}_{2}$ capture from gas-fired power plants using monoethanolamine (MEA). Int. J. Greenh. Gas Control 63, 321-328.

Sreedhar, I., Nahar, T., Venugopal, A., Srinivas, B., 2017. Carbon capture by absorption - Path covered and ahead. Renew. Sustain. Energy Rev. 76, 1080-1107.

Stichlmair, J., Bravo, J.L., Fair, J.R., 1989. General model for prediction of pressure drop anc capacity of countercurrent gas/liquid packed column. Gas Sep. Purif. 61, 19-28.

Strigle, R.F., 1994. Packed tower design and applications: random and structured packings, 2nd ed. Gulf Publishing Company, Houston.

Tontiwachwuthikul, P., Meisen, A., Lim, C.J., 1992. $\mathrm{CO}_{2}$ absorption by $\mathrm{NaOH}$, monoethanolamine and 2-amino-2-methyl-1-propanol solutions in a packed column. Chem. Eng. Sci. 47, 381-390.

Wang, M., Lawal, A., Stephenson, P., Sidders, J., Ramshaw, C., 2011. Post-combustion $\mathrm{CO}_{2}$ capture with chemical absorption: A state-of-the-art review. Chem. Eng. Res. Des. 89, $1609-1624$.

Warudkar, S.S., Cox, K.R., Wong, M.S., Hirasaki, G.J., 2013. Influence of stripper operating parameters on the performance of amine absorption systems for post-combustion carbon capture: Part I. High pressure strippers. Int. J. Greenh. Gas Control 16, 342-350.

Wolf-Zöllner, V., Seibert, F., Lehner, M., 2019. Extended performance comparison of different pressure drop, hold-up and flooding point correlations for packed columns. Chem. Eng. Res. Des. 147, 699-708.

Zhang, Y., Chen, C.C., 2013. Modeling $\mathrm{CO}_{2}$ absorption and desorption by aqueous monoethanolamine solution with Aspen rate-based model. Energy Procedia 37, 15841596.

Zhang, Y., Chen, H., Chen, C.C., Plaza, J.M., Dugas, R., Rochelle, G.T., 2009. Rate-based process modeling study of $\mathrm{CO}_{2}$ Capture with aqueous monoethanolamine solution. Ind. Eng. Chem. Res. 48, 9233-9246.

Ziaii, S., Rochelle, G.T., Edgar, T.F., 2009. Dynamic modeling to minimize energy use for 
$810 \mathrm{CO}_{2}$ capture in power plants by aqueous monoethanolamine. Ind. Eng. Chem. Res. 48, 61058116111. 